\title{
A CONCOMITÂNCIA DE AÇÕES COLETIVAS, ENTRE SI, E EM FACE DAS AÇÕES INDIVIDUAIS
}

\author{
Rodolfo de Camargo Mancuso \\ Professor Associado da Faculdade de Direito da \\ Universidade de São Paulo \\ Procurador do Município de São Paulo
}

\begin{abstract}
Resumo:
O autor aborda os seguintes itens no desenvolvimento de seu trabalho, a saber, em ordem cronológica: etiologia da convivência entre ações judiciais; os conflitos entre os direitos e os que contrapõem os interesses; os conflitos coletivos no processo civil brasileiro; a concomitância entre ações coletivas; e a coisa julgada coletiva, em face dos sujeitos concernentes.
\end{abstract}

\begin{abstract}
:
The author approaches following itens in the development of its work, to know, in chronological order: etiology of the company between legal actions; the conflicts between the rights and the ones that oppose the interests; the collective conflicts in the Brazilian civil process; the concurrence between class actions; e the collective res judicata (matter which has been previously adjudged) in final, in face of the concerning parts.
\end{abstract}

Unitermos: ações judiciais; conflitos coletivos; ações coletivas.

1. A etiologia da convivência entre ações judiciais.

O trâmite concomitante entre ações judiciais pode começar a ser analisado a partir da garantia constitucional do acesso à Justiça (CF, art. $\left.5^{\circ}, \mathrm{XXXV}\right)$, por conta da própria generalidade do direito de ação, que apresenta natureza abstrata, nesse sentido de restar assegurado tanto aos históricos de lesões sofridas como aos de lesões temidas, e isso, independentemente de as pretensões serem ou não-fundadas. É dizer, a avaliação 
quanto ao mérito das controvérsias é uma intelecção que não integra o juízo de admissibilidade, tanto das ações quanto dos recursos,' apresentando-se assim como um posterius, a ser aferido a partir do momento em que o Estado-juiz tenha reconhecido que o processo apresenta-se tecnicamente hígido, com relação às partes (legitimidade, interesse e representação), ao juiz (imparcialidade e competência), e, enfim, em face da própria relação processual em si mesma, que deve ser existente e válida.

Entre nós vem predominando a concepção da ação como direito abstrato, tomada essa abstração tanto no sentido de dispensa quanto à indagação de ser a pretensão fundada, mas, também, no sentido de sua autonomia em face da relação de direito material a que serve de veículo, fenômeno bem nítido nas ações declaratórias negativas, onde, justamente, pode-se pedir a declaração da inexistência de uma relação jurídica (CPC, art. $4^{\circ}$ ), a par da possibilidade do ajuizamento de ações que diríamos desubstantivadas, como a rescisória, fundada em nulidade do julgado rescindendo, por incompetência absoluta do juiz (CPC, art. 485, II), ou mesmo a ação direta de inconstitucionalidade, reportada ao interesse legítimo a que as leis e atos do Poder Público sejam... conformes à Constituição. Compreende-se, assim, a dicção do art. $3^{\circ}$ do CPC, de que para propor ou contestar uma ação bastam "interesse e legitimidade"

A natureza abstrata do direito de ação, todavia, está longe de ser questão fechada, bastando lembrar o sentido imanentista ou concreto, sugerido pela redação do art. 75 do Código Civil ("A todo o direito corresponde uma ação que o assegura"); aliás, a concepção demasiadamente abstrata do direito de ação já veio criticada por José Ignácio Botelho de Mesquita, Titular de Direito Processual da USP: "Parece-nos que um direito consistente no poder de pôr em movimento as sanções da lei, ao qual porém não corresponde este poder, mas apenas o de 'fazer escutar, conhecer e ponderar. as próprias razões 'é um fantasma bem mais sofisticado e surrealista que a ação na concepção de Wach" 2

1. Scm cmbargo de o art. 557 do CPC, na redação da Lei n. 9.756/98, dizer que o Relator "negará scguimento a recurso manifestamente (...) improcedente", ai trazcndo, pois, o mérito do recurso para o plano da sua admissibilidadc. Fato ć que a anterior Lei dos Recursos - n, 8.038/90, art. 38 - já utilizava tal terminologia, $\mathrm{c}$, de todo modo, tal decisão monocrática vem a scr agravável (\$ $1^{\circ}$ daquele art. 557), o que de tudo resulta, sob a óptica do Relator, numa sorte de juizo de mérito, antecipado, mas provisório. (Ao propósito, v. Nery \& Nery, "Código de Proccsso Civil, comcntado", 4" cd., RT, São Paulo, I999, nota 2 ao art. 557 do $\mathrm{CPC}$ ).

2. "Da ação civil", cd. RT, São Paulo, 1975, p. 123. 
Por outro lado, enquanto o singelo direito de petição mostra-se genérico e incondicionado (CF, art. 5, XXIV, a), já a ação, ao contrário, é específica e (muito) condicionada, explicando Moacyr Amaral Santos tratar-se de "um direito subjetivo público, distinto do direito subjetivo privado invocado, ao qual não pressupõe necessariamente, $e$, pois, neste sentido, abstrato; genérico, porque não varia, é sempre o mesmo; tem por sujeito passivo o Estado, do qual visa a prestação jurisdicional num caso concreto" ${ }^{3}$ Isso explica o grande número de circunstâncias que, uma vez ocorrentes num processo, acabam por desobrigar o Estado-juiz de pronunciar-se sobre o mérito das lides, tais os pressupostos processuais ditos negativos (litispendência, perempção, coisa julgada, convenção de arbitragem, incompetência absoluta do juiz); as condições da ação (interesse de agir, possibilidade jurídica do pedido, legitimação); sem falar em outras eventualidades (vício de representação, colusão entre as partes), que acabam por inviabilizar o enfrentamento do meritum causae: CPC, art. 267 e incisos, passim; arts. 13, 129. Apesar dessas ocorrências, que sinalizam para um non liquet de parte do julgador, ainda assim o ideal é que a cognição judicial seja plena e exauriente, nesse sentido de resolver a um tempo o processo (o continente) e a lide (o conteúdo), e outra coisa não quis o legislador, ao dizer que é ao publicar a decisão de mérito que o juiz "cumpre e acaba o ofício jurisdicional" CPC, art. 463.

Ademais, para obter um comando judicial que assegure o bem da vida objeto da pretensão, esclarece Cândido Rangel Dinamarco, "não basta ao autor ter o direito de ação e exercê-lo adequadamente. Ter ação assegura-lhe somente a obtenção do provimento de mérito, sem que este lhe seja necessariamente favorável. Para obter sentença favorável é preciso que, além de ter a ação, ele ostente una pretensão amparada pelo direito substancial (v.g., que seja realmente credor de uma indenização, como alega)" "Assim se passa porque, enquanto o Estado-Administrador atua por uma legitimação de natureza originária, ou primária, embasada num mandato decorrente da vontade popular, o que inclusive autoriza a atuação de oficio, mediante escolhas políticas e atos discricionários, já a legitimação do Estado-Juiz é de natureza derivada, institucional, decorrente da investidura de agentes recrutados por concurso público, donde caber ao julgador aplicar - mediante provocação - a norma de regência aos fatos, sob critério de legalidade estrita (CF, art. $5^{\circ}$ e inc. II; CPC, art. 127, contrario sensu), não podendo a decisão de mérito ir além, ficar aquém ou dar coisa diversa do que restou fixado como objeto litigioso (CPC, arts. $\left.2^{\circ} 128,460\right)$.

3. "Primciras linhas de Dircito Processual Civil”, v. I, cd. Saraiva, São Paulo, 1997, p. 159.

4. "Fundamentos do processo civil moderno", v. II, cd. RT, São Paulo, 2000, pp. 819-820. 
Tantas exigências de ordem formal, porém, não impedem que um número muito expressivo de históricos de lesões temidas ou sofridas afluam ao Judiciário, cabendo ao Estado-Juiz ao menos apreciar o que vem reportado, numa desejável perspectiva de facilitação do acesso à Justiça. Nesse sentido atua o princípio da indeclinabilidade (ou ubiqüidade) da jurisdição (CF, art. 5, XXXV), correspondente ao que, no processo norte-americano garante a todos o day in Court, oportunidade para que os contraditores exponham suas razões (right to be heard: o direito de ser ouvido), perante um órgão judicial competente e imparcial. Dentre nós, o Código de Processo Civil e a legislação processual extravagante buscam cumprir sua vocação instrumental, disponibilizando uma vasto receituário de ações específicas, a par de certas válvulas de segurança para hipóteses específicas ou diferenciadas, como se vê no poder cautelar geral (art. 798), na fungibilidade entre as ações possessórias (art. 920), no suprimento judicial da obrigação de fazer, de natureza infungível (art. 641).

A par disso, a ciência processual procura identificar, ao interior da sociedade, os valores e interesses mais relevantes, e, para a hipótese de entrarem em conflito, indica três tipos de processo: $(i)$ o de conhecimento $(\operatorname{cog}+$ noscere $=$ apreender detidamente), para os históricos de danos sofridos, processo voltado à decisão de mérito, onde vem priorizado o valor eliminação da incerteza, compreendendo as ações declaratórias, condenatórias, constitutivas e mandamentais, conforme o livro I do CPC e legislação complementar ; (ii) o cautelar, adequado aos danos temidos ou virtuais (direitos ameaçados), cujo mote é o valor segurança de pessoas, coisas e situações, tratado no livro III do CPC e em alguma legislação extravagante; (iii) enfim, o processo de execução, de caráter mais jurissatisfativo do que propriamente jurisdicional, já que tendente à realização do "interesse do credor" (CPC, art. 612), exigindo título liquido certo e exigível (CPC, art. 586), regulado no livro II do CPC e legislação complementar.

Vale registrar uma tendência contemporânea à relativização dos escopos antes enunciados, sob a influência do sempre renovado apelo à instrumentalidade da relação processual, com a tônica sendo reafirmada na efetividade da resposta jurisdicional, em ordem a que as lides sejam compostas de modo justo, num tempo razoável e com o menor custo, e que ao final o processo propicie a maior aproximação possivel entre o direito que assiste à parte, segundo a norma de regência, e o resultado prático decorrente do comando jurisdicional; ou seja, que ao final o processo não ofereça sucedâneos de direitos, ou prosaicos prêmios de consolação, senão que, segundo o preceito chiovendiano, efetivamente assegure, a quem tenha um direito, tudo aquilo e precisamente aquilo a 
que faz jus. No ponto, Cândido Rangel Dinamarco: "Onde for possivel produzir precisamente a mesma situação que existiria se a lei não fosse descumprida, que sejam proferidas decisões nesse sentido e não outras meramente paliativas" 5

O processo civil brasileiro vem procurando, mercê da reforma gradativamente implementada ao longo da última década, buscar essa desejável efetividade, priorizando a outorga da prestação específica do objeto através de institutos como o procedimento monitório (art. 1.102, cf. Lei n. 9.079/95), a antecipação dos efeitos da tutela (arts. 273, 461, cf. Lei n. 8.952/94), o dito efeito ativo nos agravos (art. $544, \S 3$, cf. Lei n. 9.756/98); e, de lege ferenda, cogita-se mesmo da supressão do processo executivo autônomo (livro II do CPC), como esclarece o ministro do STJ, Sálvio de Figueiredo Teixeira: “A execução será uma simples fase, sem possibilidade de embargos do devedor, a exemplo do que ocorre hoje com as ações possessórias, com as ações de despejo e com a ação de nunciação de obra nova. Dá-se, aí, um 'processo sincrético no qual se fundem cognição e execução (arts. 461 e 461-A, e 644)" "

Cabe ainda registrar que muitas pretensões resistidas ou insatisfeitas, antes represadas na chamada litigiosidade contida, acabaram tendo seu meio de expressão na Justiça, com a instituição das modalidades diferenciadas de mediação e resolução das demandas, com destaque para os Juizados Especiais, voltados às causas de menor complexidade (CF, art. 98, I e Lei n. 9.099/95), órgãos esses integrantes do Poder Judiciário (CF, art. 92, VII). A par disso, as lides, antes restritas aos conflitos entre direitos subjetivos, tiveram alargado seu objeto, recepcionando outras posições de vantagem, tais os interesses (quod inter est: o que liga um sujeito a um valor), assim entendidos: ( $i$ ) os que credenciam a atuação do sujeito, mas em modo indireto ou reflexo, como se dá na impetração de segurança para defesa de direito líquido e certo de terceiro - art. $3^{\circ}$ da Lei n. 1.533/51; (ii) os que concernem a sujeitos relativa ou absolutamente indeterminados, como os chamados interesses metaindividuais, que o constituinte titulou difusos e coletivos (art. 129, III) e o legislador ordinário trifurcou, agregando a subespécie interesses individuais- homogêneos (Lei n. 8.078/90, art. 81, I, II e III); (iii) as pretensões que não configuram direitos subjetivos propriamente ditos, mas relevam de interesses legítimos, ${ }^{7}$ como aquele que esta à base do controle direto e abstrato da constitucionalidade de leis e atos do Poder Público (ADIns, ADCon).

5. "A instrumcntalidade do processo", 6² cd. Malhciros, São Paulo, 1998, p. 298.

6. "Aspectos da reforma do Código de Proccsso Civil", Revista de Proccsso n. 95, jul.sct. 1999, p. 10.

7. Sobre os intercsses legítimos c suas implicaçõcs com outras catcgorias jurídicas, v. o nosso "Intcresscs difusos - conccito c legitimação para agir”, cap. I, 4ª cd, RT, São Paulo, 1997. 
Esse largo rol de ações disponibilizadas, segue em paralelo a uma tendência expansiva quanto à judiciabilidade de novos valores e interesses, tudo contribuindo para delinear o espectro da virtual concomitância ou mesmo da justaposição entre ações. Na etiologia desse fenômeno impende ainda considerar o fato de que, apesar de nossa jurisdição ser unitária, (por inexistir dentre nós a dualidade Justiça Ordinária/Contencioso Administrativo), nem por isso nosso ambiente judiciário deixa de ser deveras complexo, espraiado num desenho que comporta mais de uma Justiça, tanto a Federal comum (juízes federais, TRFs, STJ, STF) como a especial (trabalhista, militar, eleitoral) a par das Justiças dos Estados, em maior ou menor grau de especialização (civil, penạl, fazenda, familia, falências, registros públicos); além disso, enquanto a competência para legislar em matéria processual é federal ( $\mathrm{CF}$, art. 22, I), cabe ao Estados dispor sobre sua organização judiciária (CF, art. 125 e §1), e, concorrentemente, legislar acerca de procedimentos (CF, art. 24, XI).

Outra causa a ser considerada é que, não raro, um mesmo fato jurígeno $v g$., uma relação de serviço público pode ensejar controvérsias cujo processo e julgamento vem a ser entregue a instâncias judiciais diversas, como por exemplo a ocorrência de um ato de improbidade administrativa, sindicável em ação civil pública (Lei n. 8.429/92), sem prejuízo de paralela ação penal por corrupção passiva ou concussão. Noutro exemplo, um mesmo dano ao meio ambiente pode deflagrar, a um tempo, responsabilidade administrativa, civil e penal (CF, art. 225 , $§ 3^{\circ}$ Lei n. 6.938 / 81 , art. 14). Esses efeitos reflexos se devem a que, à semelhança da conhecida metáfora das ondas concêntricas projetadas pela pedra lançada à água, um mesmo fato jurígeno deflagra efeitos previstos e queridos e outros nem tanto, mas inevitáveis. Na perspectiva processual, essas expansões podem gerar as chamadas prejudicialidades externas, fazendo com que, por exemplo, repercutam no cível a materialidade do fato delituoso e sua autoria, quando estas questões estejam definidas no juízo penal (Cód. Civil, art. 1.525; CPC, art. 584, II), o que tem grande relevância nas condenações por crimes nas relações de consumo, para o subseqüente ressarcimento dos lesados individuais (Lei n. 8.078/90, art. 103, § 4).

Embora boa parte da conflituosidade ocorrente em sociedade acabe apreciada e dirimida por órgãos para-jurisdicionais (Tribunais de Impostos e Taxas, Juntas de Recursos em matéria previdenciária e de multas de trânsito; Tribunais Arbitrais, Comissões de Conciliação Trabalhista, Tribunais de Contas, Juizados de Paz, Tribunais Desportivos), fato é que essas instâncias não integram o Poder Judiciário - cujos órgãos constam, em numerus clausus, no art. 92 da CF e assim, frente ao princípio da ubiqüidade ou indeclinabilidade da jurisdição (CF, art. $\left.5^{\circ}, \mathrm{XXXV}\right)$ mesmo as decisões finais daquelas instâncias não ficam, em princípio, imunes a um eventual contraste 
jurisdicional, segundo a competência em razão da matéria ou da pessoa ( $v g$. , art. 33 cla Lei n. 9.307/96, sobre arbitragem; CF, art. $217, \$ \$ 1^{\circ}$ e $2^{\circ}$, sobre as lides desportivas). É dizer, a existência de órgãos para-jurisdicionais pode contribuir para alivial a carga do serviço judiciário, mas sempre numa perspectiva de que os contraditores acolham a resposta pronunciada por esses órgãos.

O crescente reconhecimento da judiciabilidade dos interesses, sobretudo dos metaindividuais, na medida em que pressupõe um distanciamento dos clássicos parâmetros da titularidade, ou da atribuição exclusiva, dá ensejo a que o juízo de admissibilidade se torne mais elástico, mais permeável, facilitando a recepção de pretensões ofertadas na dimensão propriamente coletiva; todavia, essa crescente recepção do coletivo não pode ser feita em detrimento da continuidade da apreciação das pretensões individuais, dada a garantia constitucional do cimplo acesso à justiça. Aí começam as dificuldades para o mancjo concomitante desses dois contextos, dado que cada qual releva de pressupostos específicos e pede respostas judiciárias de diversa natureza.

2. Os conflitos entre os direitos e os que contrapõem os interesses.

$\mathrm{Na}$ concepção tradicional, que remonta às fontes romanas, os direitos subjetivos, sejam os privados (que contrapõem os particulares entre si), sejam os públicos (que se exercem em face do Estado) é que se beneficiam da garantia de judiciabilidade, por se entender que, sendo esta função de natureza substitutiva (e não primária, como a instância administrativa), o litigante que toma a iniciativa da ação deve exibir a titularidade de uma certa posição de vantagem abstratamente prevista no ordenamento positivo, a qual, submetida ao contraditório, permitirá ao Estado-juiz a subsunção dos fatos à norma de regência (da mihi factum, dabo tibi jus),com vistas à resolução da lide. De observar-se que esse contexto reflete-se também no campo probatório, pelo que ao autor cabe a prova do "fato constitutivo do seu direito": onus probandi incumbit ei qui agit-CPC, art. 333, I.

Por aí se explica a tradicional exigência de que o interesse de agir em Juízo deva apresentar-se real, atual e pessoal, de sorte a que, ao menos in statu assertionis, apresentem-se coincidentes estes planos: "autor da ação - sujeito beneficiado ou em situação de vantagem pela norma de regência" ; como isso é o que comumente acontece, tal legitimação é dita ordincíria. As exceções correm por conta de situações singulares, onde, justamente, não ocorre (ou não é possível) aquela coincidência, como na ação de cobrança proposta por condômino em edifício de apartamentos, ante a 
inércia do síndico (Lei n. 4.591/64, art. 21, § único), ou a ação de investigação de paternidade proposta pelo Ministério Público (Lei n. 8.560/92, art. $2^{\circ} \$ 4^{\circ}$ ); justamente porque em casos tais dá-se uma ruptura com o esquema padrão, tal legitimação é dita extraordinária, exigindo, por isso, texto expresso que a autorize (CPC, art. $6^{\circ}$ ).

Afora os casos em que interesses convergentes têm passagem pelo Judiciário (como na jụrisdição voluntária, onde pode o juiz pautar-se por equidade CPC, art. 1.109), a regra é a jurisdição contenciosa, regulada pelo CPC e legislação processual extravagante, a qual, no plano singular, é voltada à resolução de conflitos intersubjetivos de interesses - as lides individuais. Ao propósito, esclarece Alfredo Buzaid que o projeto do vigente CPC utilizava a palavra lide "para designar o mérito da causa. Lide é, consoante a lição de Carnelutti, o conflito de interesses qualificado pela pretensão de um dos litigantes e pela resistência do outro" (cf. ítem $6^{\circ}$ da Exposição de Motivos). Essa acepção individualista está à base de muitos dispositivos processuais, como o art. 472, dizendo que a sentença "faz coisa julgada às partes entre as quais é dada, não beneficiando nem prejudicando terceiros"; o art. 264, estabilizando, num determinado momento, o objeto litigioso e os sujeitos do processo; o art. 48, considerando os litisconsortes, em regra, distintos entre si.

A jurisdição singular não perde sua vocação individualista pela afluência maior ou menor de sujeitos nos polos ativo ou passivo, mas de todo modo é muito significativa a autorização para o juiz limitar a formação de litisconsórcio muito numeroso (dito multitudinário, ou monstrum § único do art. 46, cf. Lei n. 952/94), na medida em que sinaliza que a jurisdição singular não é adequada aos conflitos que, embora relevem de direitos disponíveis, dizem respeito a um número muito expressivo de sujeitos, dado que por ai já se delinearia um possivel mega-litígio, melhor enquadrável na jurisdição coletiva: Nesse sentido, o Ministério Público de São Paulo, ao definir as características dos interesses que podem ser tratados como individuais-homogêneos, para fins de tutela coletiva (Lei n. 8.078/90, art. 81, III), prevê os que "tenham expressão para a coletividade", aí incluídos "aqueles em que haja extraordinária dispersão dos lesados" (súmula de entendimento n. 7). ${ }^{8}$ E nos conflitos envolvendo prestação de serviço educacional, o art. $7^{\circ}$ da Lei n. 9.870, de 23.11.1999 prevê que se legitimam à propositura das ações previstas na Lei n. 8.078, de 1990, "as associações de alunos, de

8. O rol das símulas de entendimento baixadas pclo Consclho Supcrior do Ministério Público paulista pode scr visto in Hugo Nigro Mazzilli, “A defesa dos interesses difusos cm Juizo", 11 " cd., RT, São Paulo, 1999, p. 371 c s. 
pais de alunos e responsáveis, sendo indispensável, em qualquer caso, o apoio de pelo menos, vinte por cento dos pais de alunos do estabelecimento de ensino ou dos alunos, no caso de ensino superior". Nem por outro motivo, nos embates entre capital e trabalho, quando a controvérsia desborda o âmbito do contrato individual, para abranger os sujeitos componentes de uma dada categoria, o conflito vem encaminhado nos moldes de dissidio coletivo (CLT, art. 857).

$\mathrm{Na}$ verdade, desde a metade do século XX vinha-se assistindo uma gradativa abertura do acesso à justiça para certos interesses de natureza coletiva, embora (ainda) em termos setoriais ou corporativos, e assim, por exemplo, a Lei n. 1.134, de 14.06.1950, conferia legitimação ativa às associações de servidores públicos; a Lei n. $4.215 / 63$, em seu art. $1^{\circ}$ e $\S$ único dava análogo poder de agir à Ordem dos Advogados do Brasil para defender os interesses de seus aderentes (hoje, art. 44 e incisos da Lei n. 8.906/94); os acionistas minoritários ficavam autorizados a promover ação de responsabilidade civil contra o administrador, por danos à sociedade anônima (Lei n. $6.404 / 76$, art. $159, \S 4^{\circ}$ ). Não resta dúvida de que tais autorizações legislativas significavam uma certa abertura em direção ao coletivo, na comparação com a clássica postura individualista, mas isso ainda em modo incipiente, dado que, visivelmente, os textos tratavam da tutela a interesses de grupos organizados.

Sucede que o fenômeno mundial da globalização e correspondente formação da sociedades de massa, já prenunciados desde a Revolução Industrial, foram gradativamente refletindo-se em todos os campos do conhecimento e das relações humanas, de tal sorte que o Direito ele mesmo um produto cultural - não tardaria a ser cooptado por essa tendência. Isso foi-se evidenciando em sucessivas normatizações de caráter multinacional, de que o Brasil foi signatário, como em matéria de letras de câmbio e notas promissórias (Convenções de Genebra sobre títulos de crédito), de direitos humanos (Pacto de São José da Costa Rica, ratificado pelo Brasil em 1992), de comércio internacional (GATT - General Agreement on Tariffs and Trade) e mais recentemente, o Pacto del Mercosur.

No campo processual, podem ser citados, na perspectiva do direito comparado, os estudos para instituição de um Código Tipo para a América Latina, e, no tocante ao ideal da pacificação dos conflitos, com justiça, as propostas que, segundo Mauro Cappelleti e Bryan Garth podem ser visualizadas em três ondas: "Podemos afirmar que a primeira solução para o acesso - a primeira onda desse movimento novo - foi a assistência judiciária; a segunda dizia respeito às reformas tendentes a proporcionar representação juridica para os interesses difusos, especialmente nas áreas 
da proteção ambiental e do consumidor; e o terceiro, mais recente-é o que nos propomos a chamar simplesmente enfoque de acesso à justiça, porque inclui os posicionamentos anteriores, mas vai muito além deles, representando dessa forma, uma tentativa de atacar as barreiras ao acesso de modo mais articulado e compreensivo" "

Sob um outro enfoque, poder-se-ia falar em direitos de primeira, segunda e terceira geração. A primeira leva dos direitos gravitava sob o primado do individualismo, com os chamados direitos fundamentais, que promanavam do jusnaturalismo (direito à vida, à liberdade, à igualdade, à propriedade), valores logo incorporados aos textos constitucionais, como nos Estados Unidos (1787), França (1791), na Declaração dos Direitos do Homem e do Cidadão (1848), e em nossa primeira Constituição republicana (1891). Essa ética pós-feudal, fundada num liberalismo laissez faire, laissez passer, viria, na seqüência, sofrer influência do chamado Estado-social (wellfare state) e dos grandes movimentos operários, assim dando origem aos chamados direitos de segunda geração - os direitos sociais - que propiciaram, dentre outros efeitos, a autonomia do Direito do Trabalho e a criação da OIT - Organização Internacional do Trabalho. As Constituições brasileiras (1934, 1946 e a vigente de 1988 - art. $6^{\circ}$ e incisos) foram sensíveis a esse movimento, trazendo capítulos dedicados aos direitos sociais, valendo mencionar, no plano da legislação ordinária, a promulgação da CLT em 1943. Hoje fala-se em direitos de terceira geração, assím equidistantes dos direitos individuais como dos valores corporativos, já agora tomando o homem em dupla projeção: de um lado, na sua integração fisica com o planeta (meio ambiente no senso naturalístico), ${ }^{10}$ e, de outro lado, na sua interação com os semelhantes, podendo falar-se de direitos de fraternidade ou de comunhão universal. Neste último plano, pontificam os chamados interesses metaindividuais, notadamente os de maior amplitude social, ditos difusos, " já normatizados dentre nós (CF, art. 129, III; Lei n. 8.078/90, art. 81, I).

Ao propósito, expõe Márcio Flávio Mafra Leal: "A igualdade das minorias, proposta pelos direitos difusos, ultrapassa critérios patrimoniais, assim como a nova concepção de direito à vida, voltado para seus aspectos qualitativos, também se desvincula de qualquer noção econômica de seu gozo. Essa especificação e

9. “Accsso à Justiça”, trad. Ellen Gracic Northflect, cd. Sćrgio Antonio Fabris, Porto Alcgrc, 1988, p. 31.

10. "Mcio ambiente: o conjunto de condiçõcs, Icis, influĉncias c intcrações de ordem física, quimica c biológica, que permitc, abriga c rege a vida cm todas as suas formas" (art. 3", inc. I, da Lci n. 6.938/81).

11. Na matćria, de modo geral, o nosso "Interesses difusos - conccito c legitimação para agir", 4" cd., RT, São Paulo, 1998. 
desdobramento levou a doutrina a lançar a idéia, com a qual se concorda, de que os direitos difusos seriam direitos fundamentais đa 3" geração, embora não haja consenso sobre esse conceito" 12

No ponto, explica Caio Tácito: "Uma nova tendência começou a se desenhar, sobretudo nas duas últimas décadas, no sentido de ampliar o âmbito dos direitos humanos de modo a abranger já não mais apenas os direitos pertinentes a uma ou mais pessoas determinadas, ou até mesmo direitos coletivos de categorias específicas, ligadas por uma relação jurídica básica (como, por exemplo, os acionistas de uma sociedade anônima, ou os membros de um condominio), mas para alcançar os interesses de grupos integrados por uma pluralidade de pessoas indeterminadas, embora vinculadas por um mesmo interesse comum. A vida moderna ressalta a importância de tais direitos que não têm titular certo, mas repercutem decisivamente sobre o bem estar, ou mesmo a sobrevivência dos indivíduos nos vários segmentos sociais a que pertencem. Aos habitantes de uma determinadas região são essenciais as condições do meio ambiente em que se integram; aos consumidores sobreleva a qualidade dos produtos ou a defesa contra manipulações de mercado; o livre acesso à informação isenta ou a proteção a valores históricos e artísticos são meios elementares de difusão e preservação da cultura" 13

Quando essas massas de interesses sem dono certo (assimiláveis às res communes omnium, e jamais às res nullius!) entram em conflito com outras massas também de largo espectro, o conflito escapa totalmente aos limites e características das conhecidas disputas intersubjetivas de tipo Tício versus Caio, de que se ocupa a jurisdição singular (CPC e legislação complementar). Neste último tipo de conflito verifica-se que as partes, tanto no polo ativo (direitos individuais/situações de vantagem) como no polo passivo (obrigações/situações de sujeição) reportam-se a condições legitimantes localizadas em algum ponto bem definido no Direito Positivo (vg., responsabilidade contratual - art. 1.056 do Código Civil; responsabilidade funcional $\mathrm{CF}$, art. $37, \S 6^{\circ}$ ); mas, quando o embate é entre interesses metaindividuais (sujeitos indeterminados/objeto indivisível) aquele esquema de legitimação simplesmente não funciona, por não se conseguir visualizar onde se encontra, como diz a doutrina italiana, o punto di riferimento, isto é, a titularidade da situação jurídica. $100,101$.

12. "Açõcs colctivas: história, tcoria c prática", cd. Sćrgio Antonio Fabris, Porto Alcgrc, 1998, p.

13. "Do dircito individual ao dircito difuso". Revista de Dircito Administrativo, v. 157, jul.sct. 1984, pp. 10-11. 
Portanto, o grande desafio do processo civil contemporâneo é saber como dar voz e voto a esses interesses a non domino, mas socialmente muito relevantes. Justamente, essa nota da relevância social é que vem sobressaindo dentre as várias propostas, e nesse sentido, o art. 129, III da CF, após exaltar a "proteção do patrimônio público e social e do meio ambiente". abre a perspectiva rumo a "outros interesses difusos e coletivos" levando a melhor doutrina a propugnar que tais interesses não estão em numerus clausus, mas sempre outros e novos podem vir a ser identificados, e, desde que socialmente relevantes, passam a beneficiar de uma idônea tutela jurisdicional (considerem-se, vg., os HIV soropositivos, os grupos ditos sem - terra, o dito povo da rua, as minorias excluídas, os lesados por certos programas governamentais, etc). No ponto, Hugo Nigro Mazzilli: "Inexiste taxatividade na defesa judicial de interesses metaindividuais. Além das hipóteses expressamente previstas em diversas leis (meio ambiente, consumidor, patrimônio cultural, crianças e adolescentes, pessoas portadoras de deficiência, investidores lesados no mercado de valores mobiliários, ordem econômica, livre concorrência) - qualquer outro interesse difuso, coletivo ou individual homogêneo pode em tese ser defendido em juízo pelo Ministério Público e demais legitimados do art. $5^{\circ}$ da LACP e art. 82 do CDC..$^{14}$

Como se nota, é o dado sócio-político-econômico que veio alterar profundamente o processo civil em terrenos até então estabilizados, como a legitimação para agir, agora desfocada do parâmetro da titularidade do direito para o binômio: relevância social do interesseladequação do representante. Em conseqüência dessa alteração na condição legitimante, o poder de agir, no caso de interesses metaindividuais, revela-se em modo concorrente-disjuntivo, ofertada a vários co-legitimados ativos: entes políticos, Ministério Público, entidades associativas, órgãos públicos (Lei n. 7.347/ 85, art. $5^{\circ}$; Lei n. 8.078/90, art. 82). Aí se nota uma clara influência do processo norte americano das class actions, onde a adequacy of representation pode vir reconhecida num dado expoente do interesse coletivo o ideological plaintiff ("Federal Rules of Civil Procedure", $\mathrm{n} 23$, $a$, cf. alteração procedida em 1966): "Um ou mais membros da classe podem ser autores ou réus numa ação no interesse de todos se (...) esses portadores tutelam correta e adequadamente os interesses da classe" No ponto, explica Cássio Scarpinella Bueno: "A preocupação em torno da representatividade adequada, portanto, é um exemplo desta adequação (e não simples abandono) dos valores tradicionais do

14. “A defesa...", cit., 11" cd., p. 91 . 
processo às implicações do processo no mundo contemporâneo. Desde que uma class action volta-se, por sua própria natureza, contra litígios de massa, passa a ser inerente à sua concepção o entendimento de que membros ausentes desta mesma classe sejam afetados por seus efeitos e pela impossibilidade de rediscussão da decisão (coisa julgada material)" is

Na experiência processual brasileira contemporânea é preciso entender que a tutela judicial comporta dois planos ou enfoques distintos, conforme se trate (i) de conflitos entre posições jurídicas individuais, aí incluídas as figuras litisconsorciais, estas resultantes de somas de direitos subjetivos ou de obrigações, manejáveis na jurisdição singular, regulada basicamente pelo CPC e legislação complementar; ou, (ii) de conflitos entre interesses metaindividuais, que devem ser conduzidos para a jurisdição coletiva (ação civil pública, ações coletivas, mandado de segurança coletivo, ação popular, $A D I n s, A D C o n$ ), porque neste plano alteram-se fundamente as categorias básicas, como a legitimação para agir, a representação processual, o contraditório, a coisa julgada, a execução. É básico, nessa parte, o disposto na parte processual da Lei n. $8.078 / 90$ - arts. 81 a 104 - que, por autorização do art. 117 traslada-se para a ação civil pública padrão (Lei n. 7.347/85) e, daí, espraia-se para todo o sistema processual coletivo. Logo, não há confusão ou zona cinzenta entre esses dois grandes regimes: impende que o jurisdicionado e o operador do Direito procurem bem informar-se acerca das possibilidades e alternativas ofertadas, e fazer suas escolhas.

Hélas, fatores diversos, que vão da mera desinformação até ao desinteresse pelo estudo e acompanhamento da evolução do Direito, especialmente o Processual, têm levado a lamentáveis equívocos no trato judiciário de conflitos metaindividuais, não raro baralhando-se conceitos e categorias que relevam dos planos coletivo e individual, tudo resultando em situações de perplexidade e de injustiça, com graves prejuízos para muitos jurisdicionados e desprestígio para o Judiciário. Mauro Cappelleti alerta que ante o acesso à Justiça desses novos interesses metaindividuais, "le vecchie regole e strutture processuali in tema di legittimazione e interesse ad agire, di rappresentanza e sostituzione processuale, di notificazione in generale, di diritto al contraditorio, di limiti soggetivi e oggettivi della cosa giudicata, cadono come castelli di carta" (grifamos). Adiante, alerta: "Diceva Bertrand Russell che l' avvocato del cambiamento ha um compito ben più difficile dell' avvocato della conservazione $\mathrm{e}$

15. "As class actions nortc-amcricanas c as açōes colctivas brasilciras: pontos para uma reflexão conjunta". Revista de Proccsso n. 82, p. 102. 
dell' ordine. Ma quando ciò che si vuol conservare non risponde più alle nuove, inderogabili necessità sociali, allora la conservazione non è più ordine" (grifamos). ${ }^{16}$

3. Os conflitos coletivos no processo civil brasileiro.

$\mathrm{O}$ acessio à Justiça dos conflitos metaindividuais, empolgando grandes massas de interesses, foi sendo gradativamente viabilizado na medida da recepção da idéia de que não apenas os direitos subjetivos, privados e públicos, poderiam ter acesso à Justiça senão também os interesses, desde que se fizesse uma releitura do critério de judiciabilidade, por modo a distanciá-lo do tradicional atrelamento à titularidade, para aproximá-lo da nota da relevância social. Como observa José Carlos Barbosa Moreira, quer se denominem essas novas posições jurídicas como "direitos dos membros da coletividade ou de interesses reflexamente protegidos" (...) "desde que se esteja persuadido - e o consenso a tal respeito, vai-se tornando universal - da necessidade de assegurar aos titulares proteção jurisdicional eficaz, não importará tanto, basicamente, saber a que título se há de dispensar tal proteção. Afinal de contas, inexiste princípio $a$ priori segundo o qual toda situação jurídica subjetiva que se candidate à tutela estatal por meio do processo deva obrigatoriamente exibir carta de cidadania entre os direitos, no sentido rigoroso da palavra" 17

É inegável que a contemporânea sociedade pluralista, competitiva e reivindicante, exige, senão a criação de um processo civil especificamente coletivo, ao menos uma adaptação acentuada de certas categorias e institutos existentes, a par de algumas inovações, e a oferta de algumas alternativas de atuação. Em certo passagem de voto proferido no STF, o Min. Sepúlveda Pertence lembra que hoje, "dos sindicatos de trabalhadores às corporações empresariais e às ordens de diversas profissões, dos partidos às entidades de lobby de toda espécie, das sociedades de moradores às associações ambientalistas, dos centros de estudo aos agrupamentos religiosos, das minorias organizadas aos movimentos feministas - tudo, são formações sociais reconhecidas, umas e outras, condutos reputados imprescindiveis à manifestação das novas dimensões da democracia contemporânea, dita 'democracia participativa' e fundada, não mais na rígida separação, sonhada pelo liberalismo individual da primeira

16. "Formazioni sociali c interessi di gruppo davanti alla giustizia civile". Rivista di Diritto. Proccssualc, n. 3, 1975, p. 388 c 402.

17. "A ação popular do Dircito Brasilciro como instrumento de tutela jurisdicional dos chamados interesscs difusos". In Temas de Dircito Processual", 2"4d., Saraiva, 1988, p. 113-114. 
hora, mas na interação cotidiana entre o Estado e a sociedade. Nesse contexto era fatal, como tem ocorrido desde o início do século, que progressivamente se viesse pondo em xeque o dogma do direito processual clássico, corolário das inspirações individualistas da ideologia liberal, qual seja, o da necessária coincidência entre a legitimação para agir e a titularidade da pretensão material deduzida em juízo" 18

Vista a questão do acesso à justiça dos interesses metaindividuais pelo ângulo estritamente processual, verifica-se que a nota da titularidade torna-se, a bem dizer, irrelevante, já que o autor da ação coletiva ( $v g$., associação, Ministério Público) não invoca pretensão própria, nem pleiteia para si nenhum bem da vida, senão que se apresenta como um adequado portador de um dado interesse coletivo, em prol de uma coletividade mais ou menos expandida. Assim, como afirma Ada Pellegrini Grinover, reportando-se a Monteleone, "os adequadamente representados não são propriamente terceiros" (...) "O mecanismo baseia-se na concepção de que o esquema representativo é apto a garantir aos membros da categoria a melhor defesa judicial, a ponto de afirmar-se que nesse caso o julgado não atuaria propriamente 'ultra partes', nem significaria real exceção ao princípio da limitação subjetiva do julgado, mas configuraria antes um novo conceito de representação substancial e processual, aderente às novas exigências da sociedade" 19

Desse contexto resulta que a fruição da utilidade afinal obtida na ação de tipo coletivo se dá, naturalmente, na dimensão coletiva em que o interesse foi tomado, e a benefício dos sujeitos concernentes, verificando-se, por exemplo, que os consumidores de certo produto serão os beneficiados pela supressão da publicidade enganosa, assim como a população ribeirinha tirará proveito da despoluição do rio. É por isso que, uma vez atendido especificamente o interesse difuso ou coletivo objetivo na ação coletiva, caso ainda sobeje resíduo pecuniário (ex., o produto da multa aplicada), este será gerido por um Fundo, que, oportunamente, o encaminhará para uma destinação adequada (Lei n. 7.347/85, art. 13; Lei n. 9.008/95).

Os pontos nevrálgicos do processo coletivo brasileiro, a reclamar maior atenção e estudo do operador do Direito e que vêm provocando maior dissídio jurisprudencial parecem residir no contraditório, na legitimação para agir e na coisa julgada, pontos que, dada sua extensão, serão na sequiência tratados conjuntamente, brevitatis causa.

18. RTJ 142/446.

19. "Da coisa julgada no Código de Defesa do Consumidor". Revista do Advogado, AASP, n. 33, dcz./1990, p. 6 (grifos no original). 
No processo civil comum, desenvolvido no plano da jurisdição singular, exige-se a comunicação dos atos e termos do processo aos legítimos contraditores, com a possibilidade de impugnação, notando-se que a preocupação com esse tópico impõe que mesmo o réu revel, se foi citado por edital ou com hora certa, beneficia de um Curador - CPC, art. $9^{\circ}$, II; e se acaso não foi citado um litisconsorte necessário, a decisão porventura proferida simplesmente não terá eficácia (CPC, art. 47 e $§$ único). É sabido que o devido processo legal compõe-se do binômio "contraditório ampla defesa" (CF, art. $\left.5^{\circ}, \mathrm{LV}\right)$, sendo certo, outrossim, que os limites subjetivos da coisa julgada restringem-se às partes do processo (CPC, art. 472), ou seja, aos que integraram o contraditório. Todo esse sistema pressupõe a premissa de que a coisa julgada material faz lei entre as partes, ficando tal situação de vantagem imune até mesmo em eventual cotejo com lei posterior ( $\mathrm{CF}$, art. $5^{\circ}, \mathrm{XXXVI)}$. Visto que todo esse contexto configura o conté́do de um processo de conhecimento (caracterizado por ensejar uma decisão de mérito), então é preciso que o continente - a relação processual - seja existente e válida, com destaque para o binômio contraditório-ampla defesa.

Esse esquema é adequado aos conflitos intersubjetivos submetidos à jurisdição singular, (mesmo quando as partes estejam litisconsorciadas), mas revelase inadaptado aos conflitos metaindividuais, manejáveis na jurisdição coletiva, e isso, dentre outros motivos, porque: A) o interesse objetivado nesse tipo de demanda vem tomado em dimensão coletiva, plano em que se tornam dispensáveis as perquirições no tocante à quantidade, identificação e domicílio dos sujeitos concernentes; B) a utilidade prática decorrente do acolhimento da demanda coletiva não reflui em prol de quem tenha sido o autor, que apenas apresentou-se e atuou como um portador adequado do interesse metaidividual, aduzindo Nery \& Nery que "para as ações coletivas na tutela de.direitos difusos e coletivos, trata-se de legitimação autônoma para a condução do processo (selbstandige ProzeBfuhrungsbefugnis), ordinária. Quando a ação coletiva for para a tutela de direitos individuais homogêneos (v. CDC 8 , pr. un. III), haverá substituição processual, isto é, legitimação extraordinária", ${ }^{20} \mathrm{C}$ ) a coisa julgada formada em ação coletiva proposta em favor de interesses individuais homogêneos atua erga omnes (Lei n. 8.078/90, art. 81, III e 103,III) podendo ser transportada para o âmbito das ações individuais no que a estas aproveite (ou seja, in utilibus), ao passo que, tratando-se de interesses difusos, ou coletivos em sentido

20. "Código de Processo Civil, anotado", 4" cd., RT, São Paulo, 1999, nota 2 ao art. 5" da Lci n. $7.347 / 85$. 
estrito, a coisa julgada atua, respectivamente, erga omnes ou ultra partes (CDC, art. 81, I e II).

Conforme esclarece Ada Pellegrini Grinover, a "coisa julgada erga omnes é uma exigência do próprio tratamento coletivo. De nada serviria tratar esses bens e interesses coletivamente, se não houvesse uma qualidade de imutabilidade da sentença que se projetasse com relação a todas aquelas pessoas que podem ser beneficiadas por esta sentença", 21

No modelo inspirador de nossa ação coletiva, - as class actions do direito norte-americano - geralmente é bastante uma informação idônea (best practible notice under the circunstances) aos sujeitos da classe concernente ao interesse objetivado, de sorte a alertá-los quanto ao ajuizamento da ação coletiva, devendo tal comunicação dirigir-se àqueles "who can be identified through reasonable effort".(item 23, c. 2.e c. 3, das Federal Rules of Civil Procedure). Através dessa comunicação, explica José Rogério Cruz e Tucci, os membros da coletividade concernente "deverão ser informados de que (A) podem requerer, no prazo fixado pelo tribunal, a exclusão da classe; (B) a sentença, favorável oụ contrária, será vinculante para todos os componentes do grupo que não requererem a sua exclusão; (C) qualquer componente da classe, que não requereu fosse excluído, pode, se desejar, intervir no processo, representado por seu advogado", 22

Essa técnica do right to opt out, informa Ada Pellegrini Grinover, veio reafirmada no caso Phillis Petroleum Co. v. Shutts (472 US 797 (1985), U.S. Report, p. 5), onde a Suprema Corte "dispensou os demais, não optantes pela exclusão, de expresso consentimento para integrar a demanda (o que corresponderia ao critério do opt in" ${ }^{23}$ É interessante observar que essa disciplina, desenvolvida em país de common law, não obstante acabou recepcionada noutro país, de família romano germânica, assim surgindo na lei da ação popular portuguesa (n. 83, de 31.08.1995), cujo art. 14 dispõe que o autor representa "todos os titulares dos direitos ou interesses em causa que não tenham exercido o direito de auto-exclusão (...)" esclarecendo o artigo seguinte que, uma vez citados, os sujeitos concernentes ao objeto da lide declaram "nos autos se aceitam ou não ser representados pelo autor ou se, pelo contrário, se excluem dessa

21. "A coisa julgada pcrantc a Constituição, a Lei da Ação Civil Pública, o Estatuto da Criança c do Adolescente c o Código de Defesa do Consumidor" In "O processo cm cvolução", cd. Forensc Universitária, 1996, pp. 148-149.

22. "Class actions c mandado de scgurança colctivo", cd. Saraiva, São Paulo, 1990, p. 15.

23. "A ação popular portugucsa: uma análisc comparativa". Revista de Processo n. 83, jul.sct.1996, p. 171 . 
representação, nomeadamente para o efeito de lhes não serem aplicáveis as decisões proferidas, sob pena de a sua passividade valer como aceitação(...)". Em princípio, prossegue o art. 19, a coisa julgada tem "eficácia geral, não abrangendo, contudo,os titulares dos direitos ou interesses que tiverem exercido o direito de se auto-excluírem da representação"

Engenhoso que seja esse regime, fato é que, dentre nós, vigora outro sistema, já que nosso legislador não achou prudente à época da edição da lei da ação civil pública - 1985 - perfilhar o critério pelo qual indivíduos podem requerer ao Juízo da ação coletiva que os exclua da coisa julgada que ali venha a se formar. Explica Ada Pellegrini Grinover: "No juízo de valor que antecedeu à escolha do legislador brasileiro, verificou-se que a extensão da coisa julgada a terceiros, que não foram pessoalmente parte do contraditório, ofereceria riscos demasiados, não arredados pela técnica do opt $o u t$, calando fundo nas relações intersubjetivas, quando se tratasse de prejudicar direitos individuais; e suscitando, ainda, problemas de inconstitucionalidade, por infringência ao contraditório efetivo e real" A técnica do opt out, prossegue a Titular de Direito Processual da USP, "certamente não se adaptaria à realidade existente no Brasil, País de dimensões continentais, deparando com enormes problemas de informação completa e correta, de falta de conscientização de parcela ingente da população, de desconhecimento sobre os canais de acesso à Justiça, de grande distanciamento entre o povo e os tribunais, tudo a desaconselhar a extensão da coisa julgada, quando desfavorável a sentença, a quem não integrou a relação processual e só foi artificialmente 'representado' pelo portador em juízo dos interesses coletivos". ${ }^{24}$

Assim descartada dentre nós a técnica opt out, incursionou nosso legislador por outras veredas, ao final optando por uma postura eclética, onde vêm aproveitados subsídios de diversa fonte, a saber: (i) o disposto no art. 18 da lei da ação popular (Lei n. 4.717/65), inspirou a redação do art. 16 da Lei n. 7.347/85, sobre a ação civil pública: a decisão de mérito forma, em princípio, coisa julgada material, erga omnes, salvo na hipótese de improcedência fundada em insuficiência de provas - a chamada coisa julgada secundum eventum litis; (ii) buscando racionalizar a coexistência, em paralelo, da ação de tipo coletivo, ajuizada por algum dos co- legitimados ativos (vg., art. 82 da Lei n. 8.078/90; art. $5^{\circ}$ da Lei n. 7.347/85; CF, art. $5^{\circ}$, XXI; LXX), com as ações individuais ajuizadas pelos sujeitos concernentes, dispôs que entre esses dois planos jurisdicionais não ocorre litispendência (art. 104 da Lei n. 
8.078/90); (iii) de todo modo, buscando prevenir eventual prejuizo que, na ordem prática, pudesse advir para os indivíduos, nosso legislador previu o transporte da coisa julgada coletiva, para o âmbito das ações individuais, mas somente no que possa favorecer as pretensões veiculadas nestas últimas (Lei n. 8.078/90, art. 103, $33 .^{\circ} \mathrm{e}$ art. 104). ${ }^{25}$

Diante da garantia constitucional do acesso à Justiça e, bem assim, considerando que no caso dos individuais homogêneos o interesse, apesar de tutelado no plano coletivo, não perde sua essencialidade individual, teve o legislador brasileiro que contemplar a hipótese de alguns sujeitos concernentes decidirem pleitear sua integração à lide coletiva, como litisconsortes; o contraponto dessa intromissão é que toda iniciativa processual envolve um risco ou quando menos um custo, e no caso, essa adesão à demanda coletiva, além de irreversível (preclusão consumativa), fará com que a coisa julgada ali formada pro ou contra - alcance também o indivíduo interveniente, o que bem se compreende, porque, tendo ele optado por tal intromissão, ipso facto tornou-se parte da demanda coletiva, e assim a ele se aplicará a regra geral, de que a coisa julgada faz... lei entre as partes.

Em face desse ônus, houve por bem o legislador oferecer a alternativa de o particular requerer o sobrestamento de sua ação individual, dentro em trinta dias contados "da ciência nos autos do ajuizamento da ação coletiva" (art. 104 da Lei n. 8.078/90, parte final), caso em que: A) se a demanda coletiva tiver sido acolhida, o indivíduo poderá dela aproveitar-se, em seu pleito particular, o que, é bem de ver, acabará induzindo a procedência da ação individual, porque o acolhimento do pedido coletivo trará embutido o reconhecimento de que a causa de pedir indicada na ação individual é...fundada (ex., ordenada na ação coletiva a supressão de certa propaganda enganosa, fica ipso facto reconhecida a nocividade de tal publicidade) e esse fundamento, assim assentado judicialmente, provavelmente acarretará o acolhimento das demandas individuais, na medida em que estas vêm igualmente reportadas à tal causa de pedir; para Ada Pellegrini Grinover, o fenômeno se explica pela "ampliação ope legis do objeto do processo, para incluir na coisa julgada a decisão sobre a causa petendi" ${ }^{26}$ Aliás, isso ocorre pela boa razão de que uma coisa não pode, ao mesmo tempo, ser e não ser: é dizer, reconhecida no plano coletivo a tese de que "o tabagismo é prejudicial

25. V. o nosso "Ação civil pública", 6 a cd., RT, São Paulo, 1999, pp. 230 c ss.

26. Da coisa julgada no Código de Defcsa do Consumidor". Rcvista da Associação dos Advogados de São Paulo, n. 33, dez.-1990, p. 8. 
à saúde" não haveria lógica em que uma ação individual, com a mesma causa de pedir, viesse rejeitada; B) se a ação coletiva for rejeitada - e dado que a coisa julgada aí formada só se transporta in utilibus para o plano individual - o sujeito lesado, que não tenha se litisconsorciado à ação coletiva, não sofrerá prejuizo, nem jurídico, nem prático, tanto podendo ajuizar sua demanda particular, como retomar o curso da que tenha ficado sobrestada.

Concede-se que, porventura, um tal sistema possa não ser o absolutamente ideal, tendo mesmo José Ignácio Botelho de Mesquita,Titular de Direito Processual da USP, aí vislumbrado um certo descompasso com o princípio constitucional da igualdade, que se projeta, no plano processual, na diretriz da igualdade entre as partes (CPC, art. 125, I). O autor visualiza a figura do réu (produtor, fornecedor) numa ação coletiva envolvendo certa relação de consumo, no contraste com uma ação individual, ressarcitória, reportada àquela mesma relação: supondo consiga o réu "superar as desvantagens que lhe são impostas no processo, logre o réu obter um julgamento de improcedência da ação, de nada lhe valerá a sentença, ainda que confirmada pelas mais altas Cortes de Justiça do País. Pelo que dispõe o Código (do Consumidor), qualquer um que se apresente como vítima poderá submetê-lo a discutir novamente toda a questão, impondo-lhe novamente toda a questão, impondo-lhe novamente o mesmo dispêndio de recursos e atividades já gastos no processo anterior, e tendo que repetir tudo isto em quantos processos lhe sejam movidos. Ou seja, a sentença que o condenar tornar-se-á imutável e indiscutível, em benefício de todos os que se pretenderam vitimas; mas a sentença que o absolver não lhe servirá para nada, podendo voltar a ser discutida por quem quer que seja" 27

$\mathrm{O}$ argumento vem assim enfrentado por Ada Pellegrini Grinover: "Na solução do Código, pelo contrário, a coisa julgada desfavorável forma-se com relação a todos os entes e pessoas legitimados às ações coletivas, deixando a salvo apenas os particulares, em suas relações intersubjetivas pessoais, os quais alcançarão uma coisa julgada normalmente restrita às partes" Adiante, admite a processualista da USP a virtualidade da ocorrência de "decisões até certo ponto contraditórias. Até certo ponto, observe-se, porque a sentença favorável da ação coletiva faz coisa julgada quanto à premissa da sentença individual; ou seja, quanto à obrigação de indenizar e à condenação genérica dela decorrente, premissas lógicas da condenação a ressarcir pessoa

27. "Na ação do consumidor, pode ser inútil a defesa do fornecedor" Revista da Associação dos Advogados de São Paulo, n. 33, dcz./1990, p. 81. 
determinada".(...) "Não se trata, porém, de uma contradição quanto aos resultados práticos do processo. E a mera contradição lógica entre julgados é fenômeno muito bem conhecido dos esquemas processuais clássicos, que não a repudiam, tendo abandonado há muito tempo as posições que levavam à exaltação do valor lógico da sentença" ${ }^{28}$

É dizer, ante a virtualidade de uma superposição entre os julgamentos nas jurisdições coletiva e individual, cuidou o legislador brasileiro de circunscrever $o$ mal maior, ou seja, o prejuizo que a rejeição da ação coletiva poderia trazer para os lesados individuais, e isso sem embargo da diversa dimensão em que o daho aparece tomado nesses dois planos, como é visível. Tal se dá principalmente quando o paralelismo se estabelece entre ação coletiva por interesses individuais homogêneos e as ações dos lesados individuais, pelo fato de que nessa espécie o interesse cuja tutela é pedida coletivamente também pertine, digamos, em quotas-partes, a cada um dos sujeitos concernentes. Considere-se, por exemplo, a divulgada ação civil pública ajuizada pela $\mathrm{OAB}$, seção de São Paulo, contra Bancos, demais instituições financeiras e empresas montadoras de veículos, tendo por objeto a defesa $(i)$ dos interesses difusos "dos potenciais consumidores contratantes do Sistema Leasing" e, (ii) "dos direitos individuais homogêneos de milhares de consumidores contratantes do sistema leasing, que já possuem contratos": ${ }^{29}$ no tocante a este último tipo de interesse, e no contraste com as ações individuais porventura ajuizadas pelos lesados, não se pode negar uma certa relação de continência (CPC, art. 104) nas causas de pedir e nos pedidos. Em casos que tais, de duas uma: ou bem o indivíduo faz fé na ação coletiva e assim a ela adere, sujeitando-se à coisa julgada que aí venha a se formar, ou bem aguarda seu desfecho para, conforme o caso, ajuizar sua ação individual ou retomar a que tenha ficado sobrestada tertium non datur!

Visto que o objeto litigioso da ação coletiva não se reduz a uma singela soma de interesses indịviduais, senão que estes ali vêm tomados em dimensão coletiva, a intervenção permitida aos sujeitos não lhes confere maior liberdade de movimento, explicando Luiz Paulo da Silva Araújo Filho que "não se tolera no processo coletivo a formulação de novas demandas, com a extensão do seu objeto litigioso aos alegados direitos pessoais dos intervenientes, porque do contrário estaria sendo admitida a tumultuária atomização de uma causa que se concebeu molecular exatamente para

28. "Da coisa julgada...", cit., Vcr. Da AASP, n. 33, p. 11 c 14 (grifado no original).

29. Proc. 1999.61.00.004437-1, Justiça Federal de São Paulo, inicial datada de feverciro de 1999. 
expandir a sua efetividade, o que, mais do que soar contraditório, violaria os princípios constitucionais que alicerçam essas ações" 30

De outra parte, nosso modelo processual para o trato concomitante das ações coletiva e individuais, parece reconhecer, ao menos implicitamente, uma certa prejudicialidade externa existente entre as causas de pedir na ação coletiva e nas demandas individuais: no exemplo antes lembrado, da ação coletiva no caso dos contratos de leasing, uma vez aí assentado qual deva ser o critério de correção dos valores das prestações, é claro que essa avaliação judicial, já por seu caráter abrangente e unitário, dentro da coletividade considerada, acabará por ser absorvida no âmbito das ações individuais, embora ainda sobeje para cada indivíduo o ônus de demonstrar e provar, na execução do julgado coletivo (Lei n. 8.078/90, art. 97) o an, o quantum debeatur, além do nexo causal em face da condenação genérica a que alude o art. 95 dessa lei. Em última análise, tal sistema evoca o trâmite já existente na jurisdição singular, quando, por exemplo, a ação civil de reparação de danos ex delicto pode ficar sobrestada, em havendo uma questão prejudicial pendente de resolução em outro feito (CP, art. 91, I, c/c CPC, arts. 265, IV, $a$ e art. 584, II). De tudo se colhe a preocupação em evitar o mal maior, que seria a ocorrência de contradição entre julgados no campo prático, que acontece quando o bem da vida assegurado numa decisão de mérito vem suprimido, esvaziado ou obstaculizado por outro comando judicial.

Enfim, a intromissão do indivíduo na ação coletiva gera, ao nosso ver, tripla conseqüencia: A) preclui, consumativamente, a outra possibilidade, que seria a do ajuizamento da ação individual ou o seu sobrestamento se já proposta (electa uma via non datur regressus ad alteram); B) sujeita o interveniente à coisa julgada que se venha a formar nessa demanda coletiva, o que, de resto, está conforme ao regime da intervenção litisconsorcial (art. 54 do CPC); C) exclui, por falta de possibilidade jurídica e de interesse processual, a ulterior extromissão do indivíduo antes aderido à demanda coletiva, visto que tal alvitre - right to opt out(?) - albergado alhures, é, todavia, estranho, senão já incompatível com o regime vigente em nosso país.

Tenha-se presente que sendo o processo uma relação de direito público, as condutas que ai se praticam devem balizar-se pela previsão na lei processual (possibilidade jurídica) e pelo interesse legítimo (necessidade-utilidade - adequação), constatando-se, por exemplo, que uma pretendida extromissão voluntária do lesado

30. "Açõcs colctivas: a tutcla jurisdicional dos dircitos individuais homogêncos", cd. Forensc, Rio, 2.000, p. 147. 
individual antes aderido à demanda coletiva parece não atender a tais quesitos, porque (i) os que já obtiveram coisa julgada favorável em ações individuais, estão imunes aos efeitos de uma eventual improcedência da ação coletiva; (ii) os demais, que não se enquadram nessa hipótese, podem optar por aguardar o desfecho da ação coletiva, e, então, de duas, uma: ou ajuízam suas ações individuais ou, oportunamente, retomam o curso daquelas que haviam ficado sobrestadas. O Direito brasileiro desconhece um tertium genus, em que o lesado individual, tendo aderido à ação coletiva, ao depois pretenda se auto-excluir aos seus efeitos, nem cabendo ao julgador, no caso, guiar-se por critério de equidade, de resto inaplicável na espécie, dado cuidar-se de jurisdição contenciosa, regulada por critério de legalidade estrita (CF, art. $5^{\circ}$ e inciso II ; CPC, arts. 127, 1.109).

\section{A concomitância entre ações coletivas.}

Tendo no item precedente considerado a imbricação entre ação coletiva e ações individuais, trataremos, agora, de enfocar a confluência entre as próprias ações de caráter coletivo, quando versem análogo objeto.

Para bem se compreender essa ocorrência, é preciso ter presente que a jurisdição brasileira é de índole nacional, nesse sentido de cobrir, unitária e indeclinavelmente, todo o espaço do território pátrio, não se sujeitando a exceções ou mitigações ratione personae, materiae, loci ou muneris, parâmetros restritivos que não concernem à jurisdição propriamente dita - vista como Poder, função ou atividade - mas antes configuram critérios determinativos da competência, esta última resultante da partilha do serviço judiciário entre os múltiplos órgãos judiciais, imposta por várias razões, que incluem a dimensão continental do país, a quantidade de processos, a diversidade das causas, os graus de jurisdição, a especialidade de algumas Justiças, etc..

Essa dimensão nacional de nossa jurisdição vem de ser reafirmada pelo STF, em certa Reclamação oposta por Banco, réu em ação civil pública ajuizada sobre relação de consumo, em face de acórdão do $1^{0^{\circ}}$ TACivil-SP que declarara inconstitucionais alguns tópicos da Lei Federal n. 7.730/89, alegando o reclamante que, tendo o Tribunal local estendido a eficácia da decisão a todo o país, houvera assim usurpado competência do STF. O ministro Ilmar Galvão, todavia, descartou o argumento: “(...) inevitável reconhecer que a eficácia da sentença, no caso, haverá de atingir pessoas domiciliadas fora de jurisdição do órgão julgador, o que não poderá causar espécie, se o Poder Judiciário, entre nós, é nacional e não local. Essa propriedade, 
obviamente, não seria exclusiva da ação civil pública, revestindo, ao revés, outros remédios processuais, como o mandado de segurança coletivo, que pode reunir interessados domiciliados em unidades diversas da federação e também fundar-se em alegação de inconstitucionalidade de ato normativo, sem que essa illtima circunstância possa inibir o seu processamento e julgamento em Juizo de primeiro grau que, entre nós, também exerce controle constitucional das leis" " ${ }^{11}$ Como esclarece E.D. Moniz de Aragão, a atuação jurisdicional "como emanação da soberania nacional, que é, se estende por todo o território do País, embora limitada, às vezes, por um ou outro caso de extraterritorialidade ou dilatada por um ou outro de ultraterritorialidade. De fato, o ato jurisdicional praticado em qualquer juízo brasileiro é válido em todo o território nacional, desde que caiba na competência (territorial ou não) de quem o praticou" 32

No plano da jurisdição singular, as ações relevam de conflitos intersubjetivos, ubicados em pessoas, coisas e situações claramente definidas, o que de algum modo facilita o encontro do foro e do Juiz competentes (ex., domicílio do réu, local de cumprimento da obrigação; residência do alimentando, etc.); e, de modo geral, a imbricação entre ações acaba satisfatoriamente dirimida mediante o emprego de institutos como a conexão, a continência, a prevenção, o conflito positivo ou negativo de competência, a litispendência, enfim o que seja preciso para garantia do non bis in idem (CPC, art. 267, art. 267, V, c/c art. 301, § $3^{\circ}$ ). Já no plano da jurisdição coletiva o problema apresenta maior complexidade, e isso basicamente por duas circunstâncias: de um lado, aí os conflitos são metaindividuais, onde o critério legitimante não pode, pour cause, promanar da titularidade do direito, devendo resultar da relevância social do interesse; de outro lado, e corolariamente, a legitimação passa a ser concorrentedisjuntiva, nesse sentido de vir deferida a um número expressivo de sujeitos, entidades e órgãos, como facilmente se constata em ações como a civil pública (Lei n. 7.347/85, art. $5^{\circ}$ ), a popular (CF, art. $5^{\circ} \mathrm{LXXIII)}$, as $A D I n s$ (CF, art. 103), o mandado de segurança coletivo (CF, art. $\left.5^{\circ}, \mathrm{LXX}\right)$, as ações coletivas fundadas em relações de consumo (Lei n. 8.078/90, art. 82).

31. Reclamação n. 602-6 - SP, rcl. min. llmar Galvão, j. 3.9.1997. Esclarecc Andrć de Carvalho Ramos que tal decisão "ć hoje precedente no Excclso Pretório, tendo sido julgada cm 03.09.1997, já na vigĉncia da Med. Prov. I.570/97, que depois foi convertida na Lci n. 9.494/97". ("A abrangência nacional de decisão judicial cm açõcs colctivas: o caso da Lci n. 9.494/97". RT n. 755, sct./98, p. 116 c 119).

32. "Comentários ao Código de Processo Civil”, v. 1I, 4 cd., Forcnse, Rio, 1983, p. 176. 
Compreende-se uma tal legitimação aberta, já que na jurisdição coletiva os sujeitos concernentes são indeterminados e o objeto é indivisível (em modo absoluto, no caso dos interesses difusos, e relativo, no caso dos coletivos em sentido estrito), o que, naturalmente, impede a afetação exclusiva do poder de agir em mãos de um só legitimado. Sucede que, enquanto na jurisdição singular a repetição de uma ação (= mesmas partes, pedido e causa) pode ser coartada pela exceção de litispendência, já outra realidade se apresenta na jurisdição coletiva, em função dos elementos diferenciais antes lembrados. Assim é que, por exemplo, sendo a ação popular um instrumento processual a serviço da cidadania (defesa do patrimônio público, lato sensu), não há como impedir, por exemplo, que ante a iminência da venda de uma empresa estatal, sucede que mais de un cidadão, em Estados diversos da Federação, resolva tomar tal iniciativa, ou que mais de uma associação de defesa de consumidores ajuíze ação coletiva objetivando a supressão de certa publicidade enganosa.

Além disso, a virtual confluência entre ações de tipo coletivo é também ensejada nisso que um mesmo fato ou situação pode deflagrar conflitos em mais de uma faixa, dentro do universo metaindividual (Lei n. 8.078790, art. 81, I, II e III), como pode dar-se, por exemplo, no embate entre os fabricantes de cigarros e os defensores da saúde da população: o interesse à proteção dos fumantes passivos é difuso; o interesse à proteção dos trabalhadores nas lavouras de tabaco é coletivo em senso estrito; o interesse ao ressarcimento das vítimas do tabagismo é individual homogêneo. Por exemplo, no caso da explosão por vazamento de gás, ocorrida em shopping center, na cidade de Osasco (SP), a Promotora Ana Lúcia Cardoso da Silva de Arrochela Lobo ajuizou ação civil pública (proc. 1959/96 - 5a Vara) a título de interesses individuais homogêneos, pleiteando "condenação, em caráter genérico, das rés pessoas jurídicas a repararem os danos sofridos por uma pluralidade de vítimas, respectivos cônjuges, sucessores e dependentes"; acolhida a demanda pelo juiz Manoel Barbosa de Oliveira (26.5.1997), veio basicamente mantida a sentença pelo TJSP (ap.71.502-4/0. Rel. Des. José Osório, j. 24.6.1999, v.u.), com a só alteração no regime de responsabilidade dos administradores pessoas fisicas - de solidariedade para subsidiariedade. Agora, figure-se que essa mesma ocorrência fatídica poderia ter sido tomada sob outras dimensões do universo metaidividual, como por exemplo o interesse coletivo do grupo, categoria ou classe dos trabalhadores nesse tipo de empreendimento comercial (lei supra, art. 81, II); ou ainda, o interesse difuso na implementação de condições básicas de segurança aos freqüentadores efetivos ou virtuais desse tipo de empreendimento.

De sorte que a indivisibilidade do objeto, aliada ao regime de legitimação 
aberta, deferida concorrente e disjuntivamente a um número expressivo de sujeitos, entidades e órgãos públicos, acabam por ensejar a virtualidade da intercorrência de mais de uma ação coletiva, o que pode ocorrer tanto na repetição de uma primeira ( $v g$., mais de uma ação popular objetivando impedir a venda de uma empresa estatal), como ainda se o universo coletivo vier tocado em mais de um ponto ( $\mathrm{vg}$., ação civil pública movida pelo M. P., com pedido mandamental para impedir veiculação de propaganda enganosa de certo medicamento - interesse difuso - paripassu com ação coletiva movida por associação, pedindo indenização aos danos causados aos usuários daquele medicamento: interesses individuais homogêneos. Não é difícil perceber que a justaposição entre ações de tipo coletivo traz complicações ainda maiores do que quando a concomitância se dá entre ações coletivas e individuais, porque nesta última ocorrência, a inexistência de litispendência fica mais evidente e o manejo concomitante torna-se mais viável, ao passo que, na conjunção de ações de tipo coletivo os perigos redobram, por conta da projeção erga omnes ou ultra partes da coisa julgada, caso em que a virtual prolação de comandos de conteúdo diverso vai propiciar contradição que não se conterá apenas no plano lógico, mas desbordará para o plano prático, como facilmente se deduz.

Exemplo emblemático de concomitância de ações coletivas envolvendo um mesmo interesse metaindividual deu-se por ocasião da venda da empresa estatal Telebrás, onde nada menos de trinta ações populares afluíram à Justiça Federal ao longo do país, todas ao fundamento genérico da proteção ao patrimônio público, e tendo por objeto o mesmo interesse difuso a que fosse impedida a propalada alienação. No caso, tratava-se - ao menos in statu assertionis de um dano de porte nacional, levando a que o foro competente fosse ou o do Distrito Federal ou o da capital de Estado (Lei n. 8.078/90, art. 93, c/c art. 90 e 117; Lei n. $7.347 / 85$, arts. $1^{\circ}$ e $2^{\circ}$; Lei $n$. $4.717 / 65$, art. $5^{\circ}, \S 3^{\circ}$ ). Essa oferta de foros alternativos, em conformidade com a diretriz da democracia participativa, acabou por ensejar o ajuizamento plúrimo de ações daquela natureza, culminando num conflito (positivo) de competência, ao final dirimido pelo STJ, pelo critério da prevenção, sendo relator o ministro Demócrito Delgado (CC 22123MG- proc. 980028122-3), assim firmada a vis attractiva do Juizo que oficiara na primeira daquelas ações, nos termos dos arts. 106, 219 do CPC, c/c Lei n. 4.717/65, art. $5^{\circ}$ \$ $3^{\circ}$ A procuradora da República, Gilda Pereira de Carvalho Berger, opinara nos autos "pela procedência do conflito e, em consequiência, seja declarado competente para o processo e julgamento das ações (...) o Juizo Federal da 13" Vara Federal de Minas Gerais, por ser o prevento (...)" e em suas razões de opinar, invocara o entendimento expendido pelo próprio Relator em outra sede (CC 19.686, DJU 17.11.97), onde este assentara: 
"O malefício de decisões contraditórias sobre a mesma relação de direito consubstancia a espinha dorsal da construção doutrinária inspirada no princípio do simultaneus processus a que se reduz a criação do forum connexitatis materialis. $\mathrm{O}$ acatamento $\mathrm{e}$ respeito às decisões da justiça constituem o alicerce do Poder Judiciário que se desprestigiaria na medida em que dois ou mais juizes proferissem decisões conflitantes sobre a mesma relação jurídica ou sobre o mesmo objeto da prestação jurisdicional. A configuração do instituto da conexão não exige perfeita identificação das demandas, senão que, entre elas preexista um liame que as torne passiveis de decisões unificadas" ${ }^{33}$

De fato, é preciso harmonizar dois valores, ambos respeitáveis e compossíveis: (i) de um lado, o direito subjetivo público ou o interesse legítimo de todo cidadão, no gozo dos direitos políticos, de participar da boa gestão da coisa pública, inclusive através da ação popular, averbando Gilda Pereira de Carvalho Berger, no parecer antes citado: "A propositura de várias ações em vários locais do País, seja pelo Ministério Público, seja pelo Autor popular é uma ação legítima e legal, tanto os cidadãos de qualquer Estado brasileiro têm legitimidade, como qualquer dos membros do Ministério Público, dentre de suas atribuições têm a função de zelar por este tipo de interesse"; 34 (ii) de outro lado, há o interesse público na preservação da higidez técnicojurídica da relação processual e na mantença da autoridade das decisões judiciais, até para que os atos ai praticados tenham validade e eficácia, tudo passando pela questão prejudicial do foro competente, que no caso antes relatado veio bem dirimida pelos institutos da conexão e da prevenção.

Otimizando-se o significado da legitimação concorrente-disjuntiva, podese dar-se, por exemplo, que na Bahia venha ajuizada ação de tipo coletivo, objetivando impedir a cogitada transposição das águas do Rio São Francisco: tal circunstância não pode operar como pressuposto negativo, a impedir que análoga iniciativa venha porventura tomada por outro co-titular desse mesmo direito subjetivo público ou desse mesmo interesse legítimo à proba e eficiente gestão do meio ambiente, que, na exata diç̧ão do art. 225 da CF é "bem de uso comum do povo" Tal entendimento, naturalmente, implica na aceitação de virtual concorrência de mais de uma ação de tipo coletivo, envolvendo análogo objeto, mas o processo civil está dotado dos meios para equacionar tal imbricação, mormente os institutos da conexão, continência e prevenção, deixando-se para os casos extremos, onde seja marcante a superposição

33. "Açõcs populares propostas contra a privatização da Telcbrás. Conflito de compctência”. Bolctim dos Procuradores da República, n. 8, dez. 1998, p. 10 c s., passim.

34. Idcm, p. 15. 
entre causas e pedidos nas ações confrontadas, a aplicação da alternativa mais radical da litispendência, que implicaria em abortar a(s) ação(ões) coletiva(s) sequenciais. ${ }^{35}$

Dizemos que o reconhecimento da litispendência deveria ser deixada para os casos extremos, para não desestimular o exercício salutar da cidadania, no contexto de uma democracia participativa, a teor do observado por Luiz Paulo da Silva Araújo Filho: "A criação de mecanismos amplos para a veiculação de ações coletivas, ademais, atende à natureza de Estado Democrático de Direito em que se constitui o Brasil, porque permite a grande participação popular através do processo" $36 \mathrm{De} u m$ lado, o próprio constituinte é que sinalizou para uma legitimação concorrente-disjuntiva nesse campo (art. 129, $\S 1^{\circ}$ ); e, bem vistas as coisas, acreditamos não seja muito comum a concomitância de ações coletivas precisamente iguais, onde coincidam os pedidos (imediato, mediato) e as causas (remota, próxima), ainda que se releve a diversidade nos legitimados ativos, em nome de sua titulação como substitutos processuais de parcelas mais ou menos expandidas da coletividade.

No ponto, entende Antonio Gidi que "se entre uma ação coletiva do CDC e uma ação civil pública, uma ação popular, um mandado de segurança coletivo ou qualquer outra ação coletiva ocorrer identidade de causa de pedir e de pedido, haverá litispendência entre essas duas ações. Serão a mesma e única ação coletiva, apenas propostas com base em leis processuais diferentes" ${ }^{37}$ A seu turno, aduz Ada Pellegrini Grinover, figurando a coexistência de uma ação civil pública e uma ação popular, sobre um mesmo thema decidendum: "Conforme o caso, poderá haver conexão entre as duas ações nos termos do art. 103, CPC (identidade de objeto ou causa de pedir) ou continência (se um pedido for mais amplo que o outro: art. 104, CPC), com as mesmas conseqüências para ambos os casos: a modificação da competência, a distribuição por dependência e a reunião de processos para decisão de mérito conjunta. Mas, é possivel avançar mais, e conforme o caso, detectar-se até a litispendência entre as duas causas" 38

35. Sobre a aplicabilidade da litispendência cntre ações colctivas, v. Kazuo Watanabc, "Demandas colctivas c os problemas emergentes da praxis forcnsc", Revista de Processo n. 67, jul./sct. 1992, p. 19.

36. "Açõcs Colctivas: A Tutcla Jurisdicional dos Dircitos Individuais Homogêncos", cd. Forcusc, Rio, 2000, p. 239, 240.

37. "Coisa julgada c litispendência cm açõcs colctivas", cd. Saraiva, São Paulo, 1995, p. 219.

38. "Uma nova modalidade de Icgitimação à ação popular. Possibilidade de concxão, continĉncia c litispendência". In "Ação civil pública. Lci n. 7.347/85- Rcminiscências c reflexões após dez anos de aplicação", cd. RT, São Paulo, 1995, p. 26. 
Aliás, como o escopo da jurisdição coletiva é a consecução de uma resposta judiciária molecularizada, que evite a fragmentação do conflito coletivo em incontáveis demandas-átomo ${ }^{39}$ assiste razão a Luiz Paulo da Silva Araújo Filho, quando assevera: "sempre que o thema decidendum for de âmbito nacional, e o autor da ação tiver representação em todo o país, a princípio deverá haver apenas uma única e exclusiva ação coletiva, como o mesmo objeto e a mesma causa petendi. A propositura de uma nova ação coletiva, idêntica (rectius: a repropositura da mesma ação coletiva), caracteriza irrefragável litispendência" 40

Naturalmente, se a concomitância ocorre entre duas ações coletivas que, posto relevem de uma mesma causa remota ( $\mathrm{vg}$., publicidade enganosa) visam cada qual a tutela de diferentes dimensões do interesse metaindividual (numa, o interesse difuso à correta divulgação dos produtos e serviços e supressão da mensagem publicitária viciada; noutra, o interesse individual homogêneo ao ressarcimento devido à comunidade dos lesados individuais), é claro que aí não se configura a litispendência, podendo, eventualmente, dar-se a continência ou a conexão, conforme se apresente o caso concreto.

5. A coisa julgada coletiva, em face dos sujeitos concernentes.

As ações de tipo coletivo - ADIns, ação civil pública, mandado de segurança coletivo, ação popular, ações em defesa de consumidores - têm em comum a característica de que o critério definidor da faixa do universo coletivo aí considerado exsurge a partir do pedido formulado, o que se explica pelo fato de que uma mesma fattispecie pode ser tomada em projeção espacial ou subjetiva mais ou menos expandida. Por exemplo: a floresta amazônica pode ser visualizada enquanto interesse difuso (defesa dessa área de preservação permanente) ou enquanto interesse coletivo em sentido estrito (povo da floresta versus madeireiras). De todo modo, ante a necessária adstringência da resposta judiciária aos lindes do pedido ( $\mathrm{CPC}$, art. $\left.2^{\circ} 128,460\right)$, este é que acabará fixando os limites do julgado, com vistas a se saber: (i) quais sujeitos serão abrangidos por seus efeitos - limites subjetivos - e, (ii) quais capítulos, pontos e questões consideram-se decididos - limites objetivos. Ambos esses limites, num determinado momento se tornarão definitivos é intangíveis, com a imutabilidade agregada pela coisa

39. V. Kazuo Watanabc, "Dcmandas colctivas...", cit., Revista de Processo n. 67, jul.sct.1992, p. 19. 40. "Açõcs Colctivas...", cit., p. 161. 
julgada material; todavia, como aí se está tratando de interesses metaindividuais, não faria sentido que a eficácia da coisa julgada ficasse restrita apenas às partes, como na jurisdição singular (CPC, art. 472), donde ser inevitável, na jurisdição coletiva, um grau de expansão extra autos, maior ou menor, de modo proporcional ao espectro do interesse considerado (Lei n. 8.078/90, art. 103 e incisos).

Assim, uma mesma controvérsia - por exemplo, as restrições ao tabagismo durante as viagens aéreas - pode ser levada à Justiça em termos de interesse difuso, coletivo ou individual homogêneo, dependendo de como venha posto o pedido: se o móvel da ação é a proteção da saúde pública, o interesse é difuso; se o intento é a defesa das condições de trabalho dos aeronautas, o interesse é coletivo em senso estrito; se a pretensão é o ressarcimento dos danos já infligidos aos passageiros e tripulantes enquanto fumantes passivos, o interesse é individual homogêneo. O exemplo evidencia que a questão da projeção da coisa julgada coletiva em face das posições individuais fica exacerbada nesta terceira modalidade, justamente por ser vocacionada a uma condenação genérica (Lei n. 8.078/90, art. 95), que opera como um modelo ressarcitório geral, a servir de base para as oportunas execuções individuais, onde os interessados provarão não só o quantum, mas também o an debeatur, a par do nexo causal. Ao propósito, esclarece Luiz Paulo da Silva Araújo Filho: "A fruição concreta do direito abstratamente reconhecido pela decisão genérica do art. 95 só é viável por meio da propositura de ações individuais, chamadas de liquidação da sentença, nas quais deverão ser comprovados, por cada um dos interessados, os fatos constitutivos específicos do seu alegado direito" 41

É preciso entender que a ação para a defesa de interesses individuais homogêneos é uma forma processual coletiva de tutela judicial, e, por isso, impende ter presente que certos institutos e faculdades próprios da jurisdição singular, ou bem aí não têm como aplicar-se, ou quando muito, devem ser manejados com refrações especiais. Assim se passa com a intromissão dos indivíduos no âmbito da ação coletiva em curso: embora permitida (art. 94 da Lei n. 8.078/90), impende sempre ponderar os riscos e os ônus daí decorrentes, já antes salientados, e mesmo o aspecto do legítimo interesse de uma tal intromissão, em se considerando que a ação coletiva vem, presumidamente, proposta a favor, e não contra tais interesses, e essa premissa está à base do transporte da.coisa julgada ali formada somente quando possa beneficiar os sujeitos concernentes. É dizer, há que se priorizar o dado de que na ação coletiva o 
interesse que constitui o objeto litigioso está sendo judicializado em sua dimensão metaindividual, com abstração, pois, dos sujeitos concernentes. A se entender de outro modo, franqueando-se livremente o acesso dos indivíduos à instância coletiva, esta acabaria por se descaracterizar como tal, ao final desfigurada numa indefinida mélange de interesse metaindividual mesclado com interesses particulares litisconsorciados.

Na matéria, esclarece Ada Pellegrini Grinover: "Quando o Código determina a extensão subjetiva do julgado para beneficiar terceiros, transportando às ações individuais a sentença coletiva favorável, outra inovação ocorre: a ampliação ope legis do objeto do processo, para incluir na coisa julgada a decisão sobre o dever de indenizar". (...) Daí decorre que "a intervenção a título de litisconsórcio não autoriza os litisconsortes a formularem pretensão indenizatória pessoal, pois isso desvirtuaria o objeto do processo coletivo e a natureza da sentença" ${ }^{42}$

Em conseqüência das precedentes colocações, fica inevitável inferir que, uma vez judicializado o conflito em termos de demanda coletiva, tornam-se inócuas as perquirições concernentes à identificação dos indivíduos concernentes (quem são? quantos são? qual seu domicílio? quais foram aderentes da associação autora?). Assim se passa porque: $(i)$ os que tenham optado por ingressar no processo coletivo passam a integrá-lo para todos os efeitos, ao nosso ver sem possibilidade de extromissão, via obstruída pela preclusão consumativa, resultante de ter a parte adotado uma das alternativas oferecidas pela norma de regência; (ii) tais sujeitos intervenientes na ação coletiva ficam submetidos à eventual coisa julgada - favorável ou desfavorável que aí se venha a formar, excluida, nesta última hipótese, a possibilidade de ulterior ajuizamento de demanda individual ou de reassunção daquela porventura sobrestada (a coisa julgada faz lei entre as partes, e o interesse discutido na ação coletiva em certo modo inclui o do indivíduo ali interveniente); (iii) os que optaram por aguardar o desfecho da ação coletiva (seja não ajuizando ação individual ou sobrestando a já proposta) não poderão ser prejudicados por eventual coisa julgada coletiva desfavorável, ficando livres para, ou ajuizar suas demandas particulares, ou retomar as que estavam paralisadas. Enfim, uma vez acolhida a ação coletiva, tanto pode dar-se o transporte da coisa julgada aí formada, em favor das demandas individuais, como é possível a execução desse julgado, uti singuli ou em modo coletivo, pelos co-legitimados ativos do art. 82, da Lei n. 8.078/90, conforme art. 97 dessa lei.

42. “Código Brasileiro de Defesa do Consumidor", 3"ed., 1993, Forense Universitária, 1993, pp. 577 c 548, nessa ordem. 
Assim, se uma associação de consumidores move ação coletiva contra um Banco em defesa dos interesses individuais homogêneos de seus investidores em poupança, ao argumento de que estes, em dado período, foram lesados por remuneração a menor, não importa a quantidade desses sujeitos, nem sua identificação, domicílio ou o que mais lhes diga respeito pessoalmente (inclusive saber se eram ou não aderentes da associação autora), e isso pela boa razão de que o objeto litigioso está sendo tomado numa certa faixa do universo coletivo, onde, bem por isso, os sujeitos são considerados indeterminadamente e o objeto é considerado em modo indivisível. Acolhida a ação, não poderia o juiz restringir, ex propria aucthoritate, o âmbito de projeção da coisa julgada apenas aos poupadores que foram aderentes da associação autora: a uma, o objeto litigioso é a formação de título condenatório a favor de toda a coletividade dos poupadores do Banco, e não de parcela deles; a duas, não cabe ao julgador delimitar a expansão da coisa julgada in concreto, tratando-se de matéria afeta à Lei Federal (CF, art. 22, I), onde se atenderá à natureza e dimensão do interesse considerado, como aliás o faz o art. 103 da Lei n. 8.078/90; e, enfim, relembre-se que a associação autora figura no processo como uma adequada representante de um interesse tomado em sua acepção coletiva, com abstração, pois, dos sujeitos a ele concernentes.

Esse ambiente judiciário diferenciado, peculiar às ações de tipo coletivo, veio bem apreendido pelo juiz federal Victório Giuzio Neto, ao decidir pedido de tutela antecipada em ação civil pública movida pelo Ministério Público federal contra a União e Bancos diversos, tendo por objeto a "proteção de mutuários que celebraram contratos do Sistema Financeiro da Habitação, neste incluídas também as Carteiras Hipotecárias, beneficiados pela regra da equivalência salarial ou comprometimento de renda, mas desguarnecidos do Fundo de Compensação das Variações Salariais que se vêem ameaçados de perderem seus imóveis em razão do descompasso entre o valor das prestações e a evolução do saldo devedor atualizado por juros e índices financeiros em relação aos ganhos salariais" Na seqüência, a decisão reporta-se a julgado proferido em matéria análoga pelo juiz José Eduardo Santos Neves: 'O que está em causa não é a disponibilidade do interesse específico ou determinado, individualmente considerado, mas, a indisponibilidade desses direitos considerados em seu conjunto, o que os altera em sua essência, pois, pela lei dialética da emergência do novo, o excesso transforma a natureza da quantidade, emprestando-lhe outra qualidade' Prosseguindo, agora no tópico concernente à extensão da eficácia do julgado, dispôs o juiz Victório Giuzio Neto: "De fato, restringir o âmbito da abrangência da presente decisão aos limites territoriais deste Juizo viria proporcionar 
a severa injustiça de criar, com base na arbitrária localização geográfica dos mutuários, um grupo especial apto a receber proteção judicial, desconhecendo as mesmas agruras impostas aos demais neste imenso país e o mais grave, pelos mesmos Réus desta ação. Acima de tudo seria privilegiar conceitos ortodoxos do processo desenhados no passado e destinados às lides intersubjetivas, em detrimento da modernização de seu conceito, introduzidas por exigências deste nosso tempo, nesta era da Internet que transformou o mundo na 'aldeia global' de que nos fala Marshall McLuhan e que ao mesmo tempo que impõe uma interdependência entre os países, tende a exigir, pela maior expectativa social decorrente do melhor nível de informação, soluções tão avançadas como as adotadas nos mais desenvolvidos". (Proc. 2.000.61.00.0336271, $24^{\text {a }}$ Vara Cível Federal, São Paulo - Capital, DOE 4.10.2.000, cad. 1, parte II, p. $39,40)$.

Nem sempre, porém, a experiência judiciária brasileira tem revelado percepção assim tão clara dos pressupostos e finalidades da jurisdição coletiva, registrando-se ainda equivocos e descompassos de diversa ordem, mormente nas ações versando interesses individuais homogêneos: ora por ai se veiculam situações melhor identificadas com litisconsórcio ativo facultativo; ora não há relação entre o objeto estatutário do ente associativo e a natureza do interesse objetivado; ora se formula pedido que não é condenatório-ressarcitório; ora as sucessivas extromissões dos sujeitos antes aderidos ao pleito coletivo acaba tornando questionável a remanescência do próprio interesse coletivo afirmado à inicial. Pior, as sucessivas intervenções governamentais no campo do processo coletivo, via Medidas Provisórias (!) só têm contribuído para tornar ainda mais nebuloso esse contexto, de que é exemplo a exigência de a inicial da ação coletiva contra entes políticos e seus órgãos correlatos vir "acompanhada da relação nominal dos seus associados e indicação dos respectivos endereços" ( $§$ único do art. $2^{\circ}$ - A da Lei n. 9.494/97, cf. M. P. n. 1984, 20ª ed., DOU 30.07.2000, p. 25). No ponto, Luiz Paulo da Silva Araújo Filho, avalia que "apesar de não se justificar, ao nosso ver, a discriminação, bem que se poderia reconhecer, a esse respeito, uma inábil reação contra a tumultuária situação instaurada pela não observância dos princípios processuais, (...) que tem permitido a propositura de repetitivas ações pseudocoletivas, por múltiplas associações e sindicatos, representativos dos mesmos interessados ou dos membros de uma única categoria, com pedidos concretos e específicos quanto aos mesmos substituídos, o que provoca, além de compreensiveis dificuldades para os réus, uma inaceitável desordem jurídica. Mas aqui se antepõe, outra vez, idêntica objeção, uma vez que não se encontra uma 
justificação razoável para a desequiparação, com a formulação da exigência somente para as ações propostas contra entes públicos" 43

Outro visivel engano no trato da jurisdição coletiva consiste na inserção (ainda via Medida Provisória!) do elemento território no corpo do art. 16 da Lei $n$. $7.347 / 85$, que visivelmente não cuida de competência e sim de limites subjetivos da coisa julgada coletiva; ao passo que, sabidamente, território é critério determinativo de competência, tema tratado no art. $2^{\circ}$ dessa lei, onde vem fixado o "foro do local onde ocorrer o dano, cujo juizo terá competência funcional para processar e julgar a causa" Para Ada Pellegrini Grinover, nessa alteração "o Executivo - seguido do Legislativo foi duplamente infeliz. Em primeiro lugar pecou pela intenção. Limitar a abrangência da coisa julgada nas ações civis públicas significa multiplicar demandas, o que, de um lado, contraria toda a filosofia dos processos coletivos, destinados justamente a resolver molecularmente os conflitos de interesses, ao invés de atomizá-los e pulverizá-los (...); em segundo lugar pecou pela incompetência. Desconhecendo a interação entre a Lei da Ação Civil Pública e o Código de Defesa do Consumidor, assim como muitos dos dispositivos deste, acreditou que seria suficiente modificar o art. 16 da Lei n. 7.347/85 para resolver o problema. No que se enganou redondamente" 44

De fato, dispondo tal dispositivo, alterado originariamente pela Medida Provisória 1.570/97, que "a sentença civil fará coisa julgada erga omnes, nos limites da competência territorial do órgão prolator (...)" sua aplicação prática conduziria a situações paradoxais, que de per si evidenciam o equívoco do texto alterado. No ponto, tivemos oportunidade de figurar uma decisão em ação civil pública transitada em julgado em São Paulo, cujo comando tenha interditado o uso do mercúrio na decantação de ouro nos garimpos ao longo de um rio que, nascendo em outro Estado, cruza o espaço paulista: "No exemplo, nenhuma eficácia - muito menos erga omnes - teria a coisa julgada, porque o inquinamento do rio, com mercúrio, continuaria ocorrendo no Estado banhado pelo trecho do rio postado a montante, e daí desceria até alcançar - e poluir - o trecho do rio situado a jusante, supostamente protegido pela coisa julgada" 45

Algo semelhante se passa com o art. $2^{\circ}$-A da Lei n. $9.494 / 97$ (antes M. P.

43. “Ações Colctivas...", cit., pp. 170-171.

44. "A ação civil pública no STJ", in "STJ - 10 anos - obra comemorativa- 1989/1999", Brasilia, 1999, p. 27.

45. Cf. o nosso "Ação Civil Pública", 6" cd., RT, São Paulo, 1999, p. 236. 
1.906-11, de 25.11.97) dizendo que "a sentença civil prolatada em ação de caráter coletivo proposta por entidade associativa, na defesa dos interesses e direitos dos seus associados, abrangerá apenas os substituídos que tenham na data da propositura da ação, domicilio no âmbito da competência territorial do órgão prolator". Note-se que tal restrição coloca-se em descompasso com o sistema de coisa julgada coletiva, onde se prevê, por exemplo, que a sentença penal condenatória repercute para beneficiar as vítimas e sucessores $-\S 3^{\circ}$ do art. 103 da Lei n. 8.078/90, e isso, naturalmente, sem restrições de ordem geográfica. Assim, observa Luiz Paulo da Silva Araújo Filho, "soa manifestamente arbitrário que a sentença penal condenatória possa produzir normalmente os seus efeitos penais em todo o País, mas se queira restringir os seus efeitos civis para beneficiar apenas as vítimas ou sucessores que tenham domicílio no âmbito da competência territorial do órgão prolator. A idéia sabe a disparate" 46

Ainda tomando aquele art. $2^{\circ}$-A da Lei n. 9.494/97, a exigência de que a ação coletiva deva "obrigatoriamente estar instruída com a ata da assembléia da entidade associativa que a autorizou" igualmente parece não se justificar: de um lado, a sindicalização é livre (CF, art. $8^{\circ}$ e inc. III); de outro lado, causa espécie apareça tal exigência apenas quanto às ações contra o Poder Público, o que configura uma desequiparação injustificada; enfim, em que pese o respeitável entendimento do STF na Ação originária 152-RS, ${ }^{47}$ a letra e a teleologia do art. $5^{\circ} \mathrm{XXI}$ da CF parecem autorizar o entendimento de que, atuando as associações em juízo, por definição, $a$ beneficio de seus aderentes, sua legitimação deflui, ou da própria relação entre o objeto litigioso e a finalidade estatutária, ou do credenciamento decorrente da lei de regência; nem por outro motivo, aliás, o art. 82, IV, da Lei n. 8.078/90, dispensa a autorização assemblear para o ajuizamento de ações coletivas pelas associações.

Em breves palavras, as alterações introduzidas no sistema de coisa julgada do processo coletivo, mormente as provindas de Medidas Provisórias, pareceram ignorar a natureza adjetiva da coisa julgada, ou seja, que ela apenas agrega uma qualidade - a imutabilidade - aos efeitos substantivos do julgado, estes sim, resultantes dos comandos declaratório, condenatório, desconstitutivo, mandamental, donde a virtual inocuidade

46. “Açõcs Colctivas...", cit., p. 168.

47. Cf. Luiz Paulo da Silva Araújo Filho, "Açõcs colctivas...", cit., p. 170, rcfcrindo a Ação Originária n. 152/RS, onde prevaleccu a tesc de ser scmpre necessária "a ata da assembléia geral que conferiu à associação poderes especificos para a demanda" 
das tentativas de mitigação da eficácia espacial ou subjetiva do julgado coletivo, pelo expediente de iterativas intervenções no capítulo da coisa julgada.

Assim é que, se o julgado coletivo determinou a supressão de publicidade sobre produto nocivo à saúde, comercializado em todo o país, e tendo sido a ação ajuizada no foro competente (no caso, tratando-se de dano de porte nacional, o da capital do Estado ou o do Distrito Federal - art. $2^{\circ}$ da Lei n. 7.347/85, c/c art. 93 da Lei n. 8.078/90), segue-se que a eficácia do julgado se projetará, naturalmente, .... até onde se estenda o interesse objetivado na ação, ou seja, no caso, por todo o território nacional. A se entender de outro modo - isto é, que a eficácia do julgado fica restrita "aos limites da competência territorial do órgão prolator" terse-ia que admitir que o produto, embora já definido judicialmente como nocivo à satide, pudesse continuar a ser consumido em outro Estado, como se possível fosse estabelecer circunscrições geográficas e discriminações entre os brasileiros em matéria de relações de consumo, tema que o próprio legislador considera de ordem pública (art. $1^{\circ}$ da Lei n. 8.078/90). Ou então, considere-se o que ocorreria numa decisão em processo coletivo versando interesse difuso, transita em julgado no Rio Grande do Sul, cominando a interdição do tabagismo nas viagens aéreas, onde se nota que o valor objetivado é a saúde dos passageiros e tripulantes no transporte aéreo: quando a aeronave transpusesse a fronteira com o Estado de Santa Catarina, ficaria liberada a restrição?!

Aliás, até mesmo em situações alheias à jurisdição coletiva, sempre que se decidam temas unitários, que não comportam fracionamentos ou limitações geográficas, também seria inócua a tentativa de circunscrever a eficácia do julgado aos limites territoriais do órgão julgador: o casal divorciado no Rio Grande do Sul, não pode retomar, alhures, outro estado civil (CPC, art. 472, segunda parte); o acusado que reincidiu em delito julgado num Estado da Federação não pode ser considerado réu primário em outro Estado; ${ }^{48}$ o contrato rescindido judicialmente na Bahia, não pode convalidar-se ou ressuscitar no Amazonas. Se assim se expande a coisa julgada nas decisões sobre temas unitários, mesmo no plano da jurisdição singular, por maioria de razão se há de reconhecer essa potencialização no plano da jurisdição coletiva, onde os interesses são metaindividuais.

Nesse sentido deve ser mencionada a diligência mostrada pelo juiz federal

48. Idcm, p. 165, nota n. 110, considerando o autor que tais hipótescs, tào cvidentes de per si, chegam atć "parcecr caricatas" 
Antônio Ivan Athie, de Vitória (ES) que, acolhendo ação civil pública movida pelo Ministério Público. contra a Caixa Econômica Federal, Banco Central e União Federal, em matéria de correção de índices do FGTS, fez constar, ao final da parte dispositiva do julgado, que fossem remetidas "cópias desta sentença aos Meritíssimos Juízes Federais desta Seção Judiciária, em razão do elevado número de ações tramitando em todas as Varas, tendo o mesmo objetivo da ora sentenciada" (proc. 95.0001119-0, 4" Vara, DOE 4.7.1997, p. 24). Visível, aí, a preocupação com o desejável tratamento judicial isonômico de um tema que, no caso, revelava-se unitário em sua natureza e nacional em sua extensão.

Claro que a jurisdição coletiva não pode sempre atender todas as expectativas dos sujeitos concernentes aos interesses ali considerados, havendo casos em que o indivíduo, mesmo desconhecendo a existência da ação coletiva, exulta em saber que é um dos beneficiados pelo julgado coletivo (Waldemar Mariz de Oliveira Júnior relata uma class action em que o dono de um posto de gasolina, tendo vendido o produto a preço superior ao tabelado, veio a ser "compelido a fornecer gasolina, gratuitamente, a todos aqueles que o procurassem, até atingir a exata quantidade que vendera acima da tabela fixada" ${ }^{49}$ Já em outros casos, os indivíduos ficam desagradavelmente surpresos quando a eficácia erga omnes do julgado coletivo, porventura desfavorável, os acaba atingindo por ricochete, como ora sucede dentre nós, em virtude da cassação de liminar que em ação coletiva suspendera a cobrança da CPMF em certo período. ${ }^{50}$

Presentemente, torna-se imperiosa uma mudança de mentalidade dos operadores do Direito, que devem ser subsidiados por correta informação técnica, para a necessária conscientização de que os conflitos de natureza coletiva, seja pelo largo espectro do objeto, seja porque empolgam um número expressivo - muitas vezes indeterminado - de sujeitos, não comportam redução aos hoje acanhados padrões do litisconsórcio, onde o que existe é uma adição e não uma síntese de interesses. Hoje mostra-se francamente intolerável a atomização do conflito coletivo, fracionado em inumeráveis demandas individuais múltiplas e repetitivas, ensejando julgamentos discrepantes ou mesmo contraditórios sobre um mesmo tema, o que a rigor configura uma sorte de inconstitucionalidade, se considerado que o princípio da igualdade de

49. "Tutcla jurisdicional dos interesses colctivos", in "A tutcla dos interesses difusos", coord. Ada Pcllcgrini Grinover, cd. M. Limonad, São Paulo, 1984, p. 23.

50. Cf. Jornal O Estado de São Paulo, 19.10.2000, p. A-3, scção "Forum dos Lcitores" 
todos perante a lei $\left(\mathrm{CF}\right.$, art. $5^{\circ}$, caput) estabelece uma isonomia substancial, e não apenas abstrata ou formal, que impende ser preservada também (ou principalmente!) quando essa norma venha interpretada e aplicada pelo Judiciário nos casos concretos. ${ }^{5 /}$

Essa preocupação com o tratamento judicial isonômico, em assuntos de natureza unitária, alcança, de modo superlativo, as relações entre a ação coletiva e as individuais ajuizadas paralelamente: é preciso compatibilizar as iniciativas judiciais dos sujeitos envolvidos, frente à lógica do sistema, de sorte a resguardar a desejável coerência entre as respostas judiciárias dadas em cada qual desses planos, como ressaltado ao longo do presente estudo. Nesse sentido, é ilustrativa a hipótese figurada por Hugo Nigro Mazzilli: "e se for julgado procedente o pedido feito em ação coletiva, com efeitos erga omnes, e, ao mesmo tempo; for julgado improcedente o pedido em ação individual com a mesma causa de pedir? Suponhamos que, na ação coletiva, a coisa julgada reconheça um direito para todos os servidores públicos; ao mesmo tempo, em ação individual, o.servidor X viu formar-se coisa julgada a negar-lhe esse direito. Acreditamos que o lesado deve ser beneficiado pela coisa julgada coletiva. Não teria sentido que o mesmo demandado fosse obrigado a pagar um benefício a todos os seus funcionários, menos a um único que o acionou individualmente, sem êxito. Além de negação ao princípio isonômico, seria a existência de coisas julgadas contraditórias, uma, aliás, de maior abrangência que a outra" 52

Em casos como esse, de flagrante discrepância entre as respostas judiciárias sobre um mesmo tema, impende evitar o mal maior, que seria o desbordamento da contradição entre coisas julgadas, do plano lógico para o plano prático. Como proposta de trabalho, pode-se pensar no transporte da coisa julgada mais benéfica, para aplicação aos casos porventura julgados de forma diversa, tendo em vista a insustentabilidade de que, num mesmo espaço-tempo, e num mesmo ambiente judiciário, uma coisa possa ser e não ser, (vg., uma coisa julgada coletiva, mandando ressarcir os danos à saúde causados pelo tabagismo, e outra, individual, negando tal ressarcimento): aplicar-se-ia, então, a parêmia odiosa restringenda, benigna amplianda. Ou então, considerando-se o princípio constitucional da igualdade de todos perante a lei - que deve abranger, por maioria de razão, a lei aplicada pelo Judiciário nos casos concretos - poderia pensar-se na hipótese de uma ação rescisória (CPC, art. 485, V),

51. Para um desenvolvimento dessa idéia, v. o nosso "Divergência jurisprudencial c Súmula vinculantc", cd. RT, São Paulo, 1999.

52. "A defesa dos interesses difusos cm Juizo", 11" cd., Saraiva, São Paulo, 1999, p. 288. 
sendo para tanto necessária uma releitura da súmula n. 343 do STF, que nega tal remédio aos casos em que o texto de regência seja "de interpretação controvertida nos Tribunais" Numa visão atualizada e progressista desse enunciado, o STJ já afirmou: "A função unificadora da interpretação da legislação infraconstitucional deve preponderar acima de princípios formais aplicados à ação rescisória" (1 " Seção, Embs. Decl. na rescisória n. ${ }^{0}$ 394-BA, rel. Min. José Delgado, j. 11.02.98, v.u., DJU 1.6.98, p. 23). ${ }^{53}$ E na doutrina, aquela súmula veio revisitada, com bons argumentos, numa leitura adaptada às necessidades contemporâneas, por Tereza Arruda Alvim Wambier. ${ }^{54}$

Esperamos que o presente estudo possa, modestamente, contribuir para uma melhor compreensão das ações coletivas - entre si e na implicação com as demandas individuais - por modo que venha sempre priorizada a natureza instrumental do processo, possibilitando que dele se extraia a maior efetividade, de tudo resultando uma resposta judiciária de qualidade, ou seja: justa, jurídica, econômica e tempestiva.

São Paulo, novembro de 2000.

53. Cf. Thcotônio Negrào, "Código de Processo Civil c Icgislação processual cm vigor", $30^{\text {" }} \mathrm{cd}$., 1999, nota 21 ao art. 485 do CPC.

54. "Sobrc a súmula n. 343", rcv. Ajuris, n. 70/113. 